\title{
Geograficzne badania migracji w Polsce po 1989 r. Geographical research on migration in Poland after 1989
}

\author{
Przemysław Śleszyński $^{1}$ (i) Krystian Heffner ${ }^{2}$ (i) Brygida Solga B $^{3}$ (C) \\ Rafał Wiśniewski ${ }^{1}$ ib \\ ${ }^{1}$ Instytut Geografii i Przestrzennego Zagospodarowania im. S. Leszczyckiego PAN \\ ul. Twarda 51/55, 00-818 Warszawa \\ ${ }^{2}$ Uniwersytet Ekonomiczny w Katowicach, Wydział Ekonomii \\ ul. 1 Maja 50, 40-287 Katowice \\ ${ }^{3}$ Politechnika Opolska, Wydział Ekonomii i Zarządzania \\ ul. Luboszycka 7, 45-036 Opole \\ psleszyn@twarda.pan.pl•krystian.heffner@ue.katowice.pl•b.solga@po.edu.pl • rafwis@twarda.pan.pl
}

Zarys treści. W artykule przedstawiono zaktualizowany skrót przeglądu geograficznych badań migracyjnych publikowanych w Polsce po 1989 r., a zamieszczony w raporcie Komitetu Badań nad Migracjami PAN (Horolets et al., 2018). W opracowaniu tym zidentyfikowano około 750 pozycji bibliograficznych z lat 1990-2017, które przypisano do następujących kategorii: teoria i metodologia geograficznych badań migracyjnych (w tym modelowanie i prognozowanie), migracje wewnętrzne, migracje zewnętrzne (emigracja i imigracja), badania terytoriów zagranicznych, badania migracji historycznych (przed II wojną światową), badania wpływu migracji na rozwój regionalny i lokalny. Nie zajmowano się mobilnością dzienną (dojazdy do pracy, szkół), turystyką (rekreacyjną, biznesową, pielgrzymkową) oraz zagadnieniami etniczności i wielokulturowości. Przegląd badań uzupełniono o najnowsze publikacje (2016-2020). Wykazano koncentrację badań w kilku ośrodkach (Warszawa - PAN i UW, Opole - kilka jednostek) oraz silne powiązanie badań migracji z zagadnieniami rozwoju lokalnego i regionalnego (zwłaszcza na Śląsku Opolskim).

Słowa kluczowe: geografia migracji, migracje zagraniczne, migracje wewnętrzne, metodologia migracji, badacze migracji, ośrodki badań migracyjnych.

Keywords: migration geography, international migrations, internal migrations, migration methodology, migration researchers, centres of migration research.

\section{Wstęp}

W 2018 r. ukazał się raport Komitetu Badań nad Migracjami PAN ${ }^{1}$ (Horolets et al., 2018), którego celem było opisanie dorobku polskich badaczy migracji po roku 1989. Zawiera on wstęp i siedem tematycznych rozdziałów, poświęconych dyscyplinom naukowym: demografii, ekonomii, socjologii, politologii, historii, antropologii i geografii. W prace nad raportem zaangażowało się 21 osób z kilkunastu ośrodków w Polsce. W przypadku badań geograficznych (i studiów regionalnych) załączony wykaz pozycji (ponad 750 rekordów) stanowi najwięcej spośród wszystkich dyscyplin (około 30\%)². Wynika to jednak częściowo

${ }^{1}$ W niniejszym artykule wykorzystano, za zgodą Wydawcy, obszerne fragmenty „Raportu o stanie badań nad migracjami w Polsce po 1989 roku”, wydanego przez Komitet Badań nad Migracjami przy Prezydium PAN.

2 Literaturę zestawili członkowie Komisji Geografii Osadnictwa i Ludności PTG przy współpracy pracowników IGiPZ PAN (Ariel Ciechański, Katarzyna Goch, Filip Piotrowski, Beata Zielińska). 
z faktu, że pozostałe dyscypliny skupiły się niemal wyłącznie na migracjach międzynarodowych, a w rozdziale dotyczącym geografii dodano wiele prac ekonomicznych, socjologicznych itd., wyraźniej podejmujących problematykę rozwoju regionalnego i lokalnego, uwarunkowaną przestrzennymi procesami migracji. Tym niemniej, ilościowy wkład geografii w badania migracyjne wydaje się niepodważalny, jako że inne dyscypliny w analogicznym okresie (1990-ok. 2016) wykazywały znacznie mniejszą liczbę prac (np. socjologia - ok. 200).

$\mathrm{Na}$ tym tle celem niniejszego artykułu jest próbą bardziej przekrojowej i pogłębionej syntezy dorobku geograficznego w zakresie badań migracji po 1990 r. Specyfika badań geograficznych nad migracjami (podobnie jak badań geograficznych w ogólności) polega bowiem na wielości ujęć przedmiotowo-problemowych oraz różnorodności orientacji metodologicznych, jak też sposobów interpretacyjnych, wykorzystywanych narzędzi badawczych itd. Badania te prowadzone są głównie z pozycji empirycznych (scjentystycznych), a następnie humanistycznych i niekiedy behawioralnych. Przedmiotem badań jest przede wszystkim samo zróżnicowanie przestrzenne natężenia i kierunków migracji w różnych skalach terytorialnych, jak też szeroko rozumiane przyczyny i skutki ruchów wędrówkowych. Stosunkowo duża liczba badań wykorzystuje też zjawisko migracji jako jedną ze zmiennych tłumaczących szersze, bardziej kompleksowe procesy społeczno-gospodarcze, w tym urbanizację (zwłaszcza suburbanizację), depopulację, tworzenie się obszarów problemowych, zasięgi oddziaływania miast, zmiany w strukturze demograficznej, zawodowej i etnicznej, funkcjonowanie rynków pracy, zagadnienia rynków nieruchomości, rozwoju miast, przeobrażeń wsi i in.

Z powyższych powodów procesy migracyjne są bardzo częstym bezpośrednim i pośrednim przedmiotem zainteresowania geografów społeczno-ekonomicznych. Poważnym problemem przy tworzeniu wyczerpującego przeglądu badań jest zatem duża liczba opracowań, w których w mniejszym lub większym stopniu analizowane są migracje lub wskaźniki bazujące na pomiarze ruchu wędrówkowego. Równocześnie istnieje trudność identyfikacji typowych prac „geograficznych”, bowiem jest tu możliwa identyfikacja zarówno przedmiotowa (wynikająca z definicji geografii migracji), jak też podmiotowa (wynikająca z klasyfikacji dyscyplinarnej ośrodków, podejmujących badania nad migracjami, będące z natury obiektem zainteresowania różnych nauk, głównie społecznych).

Z powodu zainteresowania migracjami jako wskaźnikiem (predykatorem) rozwoju społeczno-gospodarczego, zakres badań w niniejszym opracowaniu ograniczono do stałych lub długookresowych przemieszczeń ludności. Tym samym z całego zjawiska mobilności (ruchliwości) wyłączono dojazdy do pracy, usług (np. szkół średnich i wyższych) oraz wyjazdy turystyczne (w tym pielgrzymkowe). W zasadzie nie brano też pod uwagę dorobku geografii etnicznej, religii i kulturowej, które są istotnie skorelowane z badaniami migracji.

Wstępna analiza bibliografii, jak też ogólna znajomość badań prowadzonych przez geografów nad migracjami w Polsce, pozwoliła na wyróżnienie następujących grup zagadnień tematycznych:

- teoria i metodologia badań,

- migracje wewnętrzne (wewnątrzkrajowe),

- migracje zewnętrzne (zagraniczne),

- badania terytoriów zagranicznych,

- historyczne badania migracji,

- badania wpływu migracji na rozwój regionalny i lokalny. 


\section{Źródła danych}

Badania geograficzne nad migracjami mają długą tradycję. Przegląd starszych prac (do ok. 1993 r.) zawierają studia Jagielskiego (1994) i Kusińskiego (1994). Następnie Gawryszewski (1997) zestawia obszerną bibliografię dotyczącą ruchliwości (mobilności) ludności Polski za lata 1896-1990, liczącą w sumie blisko 1540 pozycji.

Natomiast podstawą do przygotowania niniejszego opracowania był rozdział nt. perspektywy geograficznej i studiów regionalnych w raporcie KBnM PAN (Horolets et al., 2018), który obejmował kwerendę literatury za lata 1990-2016 (dodano również kilka prac z lat 2017-2018), zaktualizowany o nieuwzględnione uprzednio pozycje literatury za lata 2017-2020. Taki zakres czasowy jest dość symboliczny, zamyka bowiem niejako okres badań migracyjnych przed wielką pandemią koronawirusa SARS-CoV-2, która najprawdopodobniej trwale wpłynie na mobilność ludności w przyszłości.

Wyselekcjonowana baza liczy, jak wspomniano, około 750 pozycji i dotyczy istotnych prac (w tym monografii, rozdziałów w monografiach, artykułów w czasopismach i seriach wydawniczych) opublikowanych głównie przez osoby zatrudnione w ośrodkach geograficznych w Polsce ${ }^{3}$, a także w niektórych innych jednostkach (np. Instytut Rozwoju Wsi i Rolnictwa PAN, Centrum Europejskich Studiów Regionalnych i Lokalnych Euroreg UW, Wydział Nauk Ekonomicznych SGGW). Ze względu na specyfikę przedmiotowo-podmiotową geografii migracji, baza ta była uzupełniana kwerendą w innych ośrodkach i wśród badań zrealizowanych przez nie-geografów. W tym przypadku podstawą wyróżnienia było istotne uwzględnianie w analizach czynnika zróżnicowania przestrzennego migracji.

W niniejszym artykule siłą rzeczy zaistniała konieczność znacznej selekcji publikacji; ostatecznie wybrano około 180 najważniejszych prac, możliwie reprezentatywnych dla poszczególnych ujęć i nurtów badawczych oraz ośrodków prowadzących badania. Przy tym w szczególności starano się uwzględnić prace będące monografiami oraz publikowane w wiodących czasopismach krajowych i zagranicznych.

\section{Teoria i metodologia geograficznych badań migracji}

Geograficzne badania koncepcyjno-teoretyczne nad migracjami rozwijały się w Polsce zwłaszcza od lat 60. XX w. i wiążą się z tzw. szkołą prof. Kazimierza Dziewońskiego (1910-1994). W ramach tej szkoły bardzo silny był udział zainteresowań związanych z kształtowaniem się systemów miejskich i aglomeracji oraz dotyczących procesów urbanizacyjnych. Ponieważ w okresie powojennym na wzrost ludnościowy miast zasadniczy wpływ miała przyśpieszona industrializacja zapóźnionego agrarnie kraju (i tym samym duży popyt na pracę), mobilność ludności była istotnym składnikiem wyjaśniającym, względnie przyczynowo-skutkowym zachodzących procesów społeczno-gospodarczych. Wówczas powstało kilka prac, które utworzyły swego rodzaju „kanon” teoretyczno-koncepcyjny i metodologiczno-analityczny we współczesnej polskiej geografii migracji. Wymienić tu należy zwłaszcza dwie monografie powstałe w Instytucie Geografii i Przestrzennego Zagospodarowania PAN (Dziewoński et al., 1977; Dziewoński i Korcelli, 1981), w których procesy migracyjne osadzono w ramach szerszych koncepcji i teorii urbanizacyj-

\footnotetext{
${ }^{3}$ Ich lista jest dostępna na stronie internetowej Komitetu Nauk Geograficznych PAN: https://kng.pan.pl/ geografia-polska/osrodki-geograficzne-w-polsce/
} 
nych. Dużą rolę w geografii pełniło systematyczne upowszechnianie głównych kierunków badań międzynarodowych, np. koncepcji przejścia mobilności przestrzennej Zelinsky’ego, hipotez Lowry'ego, modelu grawitacyjnego Ravensteina i in., poprzez wydawnictwo „Przegląd Zagranicznej Literatury Geograficznej”. Migracjom poświęcono 2 tomy tej serii, w tym szczególną rolę odegrał tom zredagowany przez Gawryszewskiego (1972). Tłumaczenia prac tam zawartych są często cytowane do dziś.

Spośród innych obszerniejszych studiów wymienić można wcześniejszą pracę doktorską Gawryszewskiego (1974), w której rozwinął koncepcję substytucji migracji stałych i dojazdów do pracy, monografię Rykla (1985), stanowiącą wyczerpujące opracowanie na temat hierarchii migracyjnej miast w Polsce) oraz monografię habilitacyjną Gawryszewskiego (1989) na temat przestrzennej ruchliwości Polski w długim, kilkudziesięcioletnim okresie. Często cytowaną pracą, wprawdzie nie w całości, ale w dużej mierze poświęconą zagadnieniom migracyjnym (odpływu) jest studium Eberhardta nt. regionów depopulacyjnych Polski (Eberhardt, 1989). Istotną rolę metodologiczną pełniły też opracowania Jagielskiego, a także jego podręcznik geografii ludności (1974), w którym zagadnieniom migracji poświęcono szczególnie dużo miejsca.

Wymienione wyżej studia ukierunkowały w dużej mierze poglądy teoretyczno-koncepcyjne i warsztat metodologiczny, związany z badaniem zróżnicowania przestrzennego oraz natężenia ruchów migracyjnych z pozycji geograficznych w ostatnich dekadach.

Kompleksowego przeglądu teorii migracyjnych w geografii dokonuje Janicki (2007), wyróżniając jako typowo geograficzne dwie koncepcje, bazujące na modelu grawitacyjnym (Ravenstein) oraz przejściu migracyjnym (Zelinsky). Ocenia przy tym, że stanowią one powszechnie stosowany standard w badaniach geografów nt. wyjaśniania różnego rodzaju procesów związanych z mobilnością ludności, ale zarazem twierdzi, że w sensie metodologicznym, a częściowo koncepcyjno-teoretycznym, teorie te wyczerpały się (zwłaszcza model grawitacyjny), a próby sformułowania bardziej uniwersalnych koncepcji, które łączyłyby osiągnięcia różnych dyscyplin nauk społecznych, dotychczas nie powiodły się.

Jeśli chodzi o metodologię, w Polsce po 1990 r. powstało dość dużo prac, doskonalących narzędzia badań geograficznych nad migracjami i ich zastosowanie w różnego rodzaju typologiach, hierarchizacjach, delimitacjach itp. przestrzennych systemów społeczno-ekonomicznych, w tym osadniczych. Chronologicznie wymienić tutaj można zwłaszcza prace prowadzone w ośrodku wrocławskim nad wyznaczaniem regionów migracyjnych i symulacyjnymi modelami przepływów (Huk, 1991), krakowskim nad typologią miast w zakresie natężenia i kierunków migracji (Długosz, 1992a), poznańskim nad zasięgami i strefami ciążeń (Churski et al., 1996), a ponadto warszawskim nad konstrukcją syntetycznych wskaźników migracyjnych. Był to udział Kupiszewskiego w międzynarodowych zespołach (Bell et al., 2015; Stillwell, 2016; Rees, 2017) oraz opracowanie dwóch nowych wskaźników: hierarchiczno-migracyjnego (Śleszyński, 2015) oraz atrakcyjności migracyjnej (Śleszyński, 2020). Stosunkowo pokaźna jest też liczba prac, w których wykorzystywane są wskaźniki migracji (odpływu, napływu, salda, efektywności, obrotu i in.) do identyfikacji lub objaśniania innych zjawisk i procesów (delimitacja obszarów depopulacyjnych i problemowych, miejskich obszarów funkcjonalnych, szacowanie popytu na mieszkania i in., np. Śleszyński et al., 2020).

Odrębnym i wyróżniającym się zagadnieniem jest prognostyczne modelowanie migracji, w którym geografowie mieli od lat 70. XX w. silną pozycję, także zagranicą. Nawiązanie kontaktów z Instytutem Stosowanej Analizy Systemowej (IASA) w Laxenburgu k. Wiednia spowodowało rozwój prac nad złożonymi projekcjami wieloregionalnymi, których istotą 
były przepływy migracyjne populacji w różnych kategoriach wieku między różnie definiowanymi terytoriami (regionami). Wśród Polaków badania te zapoczątkował Korcelli (1982, 1992a, 1993; Korcelli i Kupiszewski, 1992), implementując na krajowym gruncie projekcje wieloregionalne Rogersa-Castro.

W późniejszych latach analizy tego typu kontynuował oraz znacznie rozwinął w swej pracy habilitacyjnej demograf i geograf Kupiszewski, podsumowując doświadczenia dotyczące modelowania struktury i dynamiki biologicznej ludności w warunkach wzrostu znaczenia migracji międzynarodowych (Kupiszewski, 2002). W studium tym przedstawiono koncepcję integracji trzech słabo dotychczas powiązanych komponentów demograficznych i prognostycznych: przestrzennej dynamiki dużych systemów ludnościowych, migracji międzynarodowych (z uwzględnieniem wpływu rozszerzenia Unii Europejskiej (UE) na mobilność ludności i kierunki ich przemieszczeń) oraz migracji wewnętrznych (z uwzględnieniem procesów urbanizacyjnych, jak m.in. suburbanizacja i kontrurbanizacja). W tym celu opracowano i zaprojektowano w systemie komputerowym oryginalny model MULTIPOLES, bazujący na doświadczeniach projekcji wieloregionalnych. Na bazie wypracowanej tam metodologii możliwe okazało się tworzenie prognoz dużych wielonarodowych regionalnych układów przestrzennych (Kupiszewski, 2013). Duża część publikacji Kupiszewskiego powstała w założonym i kierowanym przez tego badacza Środkowoeuropejskim Forum Badań Migracyjnych i Ludnościowych (2002-2012) np. Forum to powstało jako partnerstwo naukowe szwajcarskiej Fundacji na rzecz Populacji, Migracji i Środowiska (PME), Instytutu Geografii i Przestrzennego Zagospodarowania PAN oraz Międzynarodowej Organizacji ds. Migracji (IOM).

Spośród innych zagadnień, dotyczących obserwowanych i prognozowanych zagadnień migracyjnych, a mających znaczenie dla koncepcyjno-teoretycznego rozwoju badań migracyjnych w Polsce wymienić należy zwłaszcza wkład w dyskusję nad międzynarodowymi migracjami kompensacyjnymi (Korcelli, 2004), w tym studium ich potencjalnego wykorzystania dla ożywienia polskich regionów wyludniających się (Janicki, 2015).

W opolskim ośrodku naukowym rozwinięto natomiast teoretyczne rozważania na temat koncepcji regionu migracyjnego. Dokonując analizy teorii rozwoju regionalnego oraz teorii migracyjnych pod kątem ich wykorzystania do wyjaśniania zjawisk mobilności w regionie migracyjnym, a jednocześnie bazując na bogatych doświadczeniach migracyjnych województwa opolskiego i innych regionów w Polsce oraz za granicą z wyraźnie wyodrębniającym się czynnikiem migracyjnym rozwoju, wskazano na mechanizm powstawania takiego obszaru oraz cechy dystynktywne odróżniające go w przestrzeni (Heffner i Solga, 2013; Solga, 2013c). Tu również rozwinięto teoretyczno-empiryczne analizy dotyczące wpływu migracji na rozwój regionów. W tym ostatnim kontekście zwrócono uwage na dwubiegunowy charakter możliwości rozwojowych regionów migracyjnych. Ustalono, że jeśli w strukturze migracji zagranicznych przeważają wyjazdy czasowe i jednocześnie dokona się udany transfer dochodów migracyjnych oraz kapitału pozamaterialnego migrantów do regionu pochodzenia, sytuacja ta może stymulująco wpłynąć na jego rozwój. Jeśli natomiast region dotknięty zostanie znacznym i trwałym odpływem ludnościowym, stopniowo ograniczy on jego możliwości rozwojowe i na zasadzie kumulatywnej oraz okrężnej przyczynowości region stanie się obszarem depopulacyjnym i zmarginalizowanym (Solga, 2013c).

Istotne znaczenie dla rozwoju badań ma też szereg prac, wykazujących niezgodności statystyki rejestracji zdarzeń migracyjnych z rzeczywistością. Jako pierwsi z geografów 
wskazywali na to zwłaszcza Korcelli (1997a), a próby empiryczne na obszarze Śląska Opolskiego zainicjował Heffner w swoim zespole (Heffner i Solga, 1999; Dybowska, 2013). Podobne studia od wielu lat na Opolszczyźnie prowadzą ekonomiści Jończy (2003, 2012) i Rokita-Poskart (2016), które są równocześnie przykładem badań terenowych, typowym dla warsztatu geograficznego. Następnie w skali całego kraju problemem nierejestrowanych migracji zajmował się Śleszyński (2005b), wykazując charakterystyczne niezgodności w różnych skalach terytorialnych (gmin, powiatów) między spisem powszechnym a rejestracją bieżącą (niedoszacowanie atrakcyjnych aglomeracji, przeszacowanie regionów peryferyjnych). Najbardziej szczegółowym badaniem pozostaje w tym zakresie opracowanie na podstawie baz ZUS dotyczące porównania adresów zameldowania i korespondencyjnych w województwie mazowieckim (Śleszyński, 2011a). Ustalenia te są o tyle istotne, że zdecydowana większość badań geograficznych wykorzystuje wtórne dane statystyczne, pochodzące przede wszystkim z rejestracji bieżącej zameldowań i wymeldowań, względnie spisów powszechnych (zagadnienia pochodzenia terytorialnego mieszkańców). Wyjątkowe są opracowania bazujące na innych materiałach źródłowych, np. kwerendzie i częstotliwości przestrzennego występowania nazwisk polskiego brzmienia w bazach niemieckich (Kowalski i Śleszyński, 2010).

\section{Migracje wewnętrzne}

Wśród prac migracyjnych prowadzonych przez geografów lub w ośrodkach geograficznych publikacje po roku 1989 poświęcone migracjom wewnętrznym stanowiły około 40\% ich liczby, a więc były dominujące. Wyróżnić można tutaj kilka głównych obszarów zainteresowań, zależnych od skal terytorialnych:

- badania w skali całego kraju, w tym dość często w powiązaniu z innymi elementami struktury i dynamiki ludności (przyrost naturalny, struktura biologiczna itp.), w tej kategorii mieszczą się też badania zasiedziałości terytorialnej, zwłaszcza w związku z przemieszczeniami wywołanymi II wojną światową (Kosiński, 1960);

- badania w skali regionalnej, najczęściej województw, w tej kategorii wyróżniają się liczebnie prace dotyczące Śląska Opolskiego (wyodrębnione w osobnym podrozdziale);

- badania dotyczące wybranych kategorii funkcjonalnych jednostek administracyjnych, w tym zwłaszcza grup miast, w tej kategorii wyróżniają się badania poszczególnych miast jako ośrodków napływów (w tym studia przypadków) i zasięgów ich oddziaływania;

- badania w skali złożonych systemów osadniczych - obszarów metropolitalnych i aglomeracji, w tym rozwoju stref podmiejskich i migracji wewnątrzmiejskich.

Każda z tych kategorii ma swoją specyfikę, związaną najczęściej z tradycjami i „szkołami" geograficznymi ośrodków prowadzących badania, jednak zdecydowanie dominujący jest nurt opisowy, związany z identyfikacją i ustalaniem różnego rodzaju prawidłowości (przestrzennych, genetycznych, morfologicznych, strukturalnych, dynamicznych i przyczynowo-skutkowych) na podstawie, natężenia i kierunków przemieszczeń obserwowanych w danym czasie lub różnych przekrojach czasowych. Służy to następnie do formułowania bardziej ogólnych modeli, dotyczących zwłaszcza urbanizacji, rozwoju stref podmiejskich, hierarchii miast, cyklów życia miast i in. (Zborowski, 2005). 
Jeśli chodzi o badania w skali całego kraju, to rozwinęły się one zwłaszcza w latach 70. XX w. we wspomnianej szkole prof. Dziewońskiego. Po 1990 r. kontynuowali je jego uczniowie w IGiPZ PAN. Dzięki zgromadzonym długim seriom obserwacyjnym, dokonywano analiz dotyczących całego okresu począwszy od 1918 r. do czasów współczesnych (Gawryszewski, 1992, 2005). Zagadnienia te znalazły się też w Atlasie Rzeczypospolitej Polskiej. Wiele stosunkowo obszernych opracowań powstało jako części większych studiów, poświęconych zwłaszcza procesom rozwoju regionalnego i lokalnego, urbanizacji, zmian demograficznych (rozumianych jako np. przyrost lub ubytek rzeczywisty składający się z części dotyczącej ruchu naturalnego i migracyjnego) i in. Aktualnie najbardziej szczegółowym opracowaniem jest studium Śleszyńskiego (2018, aktualizacje w kolejnych latach w dorocznych raportach RRL) zawarte w dorocznym raporcie Rządowej Rady Ludnościowej, bazujące na międzygminnej macierzy zameldowań i wymeldowań za okres 1989-2018.

Ponadto w literaturze można spotkać wiele opracowań dla całego kraju, dotyczących różnych okresów transformacji (Kupiszewski et al., 1998a; Szymańska, 2000; Heffner, 2012). Wraz z postępowaniem procesów depopulacji, badano migracje dotyczące terenów wiejskich (np. Stanny, 2000; Heffner i Kamińska, 2011; Wesołowska, 2011; Rosner, 2010, 2014; Rauziński i Szczygielski, 2016), do i z miast różnej wielkości (np. Długosz, 1991, 2006; Szymańska i Hołowiecka, 2000a; Kwiatek-Sołtys, 2006), wpływ ruchów wędrówkowych na biologiczne starzenie się społeczeństw (Heffner et al., 2019), jak też same migracje osób starszych (Potrykowska, 2003; Kurek, 2006; Pytel, 2017) oraz problem wewnętrznego drenażu mózgów (Czapiewski, 2007; Janc et al., 2012; Herbst, 2015; Dolińska et al., 2020).

Znacznie więcej prac dotyczy poszczególnych regionów, co wynika z naturalnych zainteresowań badaczy w ośrodkach geograficznych i ekonomicznych w Polsce. Szczególnie dobrze rozwinęły się badania Polski południowej. Na pierwszy plan wysuwa się region opolski, którego bibliografia migracyjna po 1989 r. liczy około 300 pozycji (m.in. Dybowska, Heffner, Jończy, Kubiciel-Lodzińska, Rauziński, Rokita-Poskart, Solga, Szczygielski). Najważniejsze publikacje wywodzące się z tego kręgu zostały omówione głównie w części dotyczącej migracji zagranicznych oraz wpływu migracji na rozwój. Dużo prac powstało też na temat Małopolski (Długosz i Kurek, 1998; Długosz, 2003), Górnego Śląska (Runge, 1998; Szajnowska-Wysocka, 1999; Kłosowski i Runge, 2000, 2010) oraz Dolnego Śląska (Huk, 1991, 2004; Grabowska i Jończy, 2013; Dolińska et al., 2020). Z kolei w północnej Polsce rozwinęły się badania ruchów migracyjnych Pomorza Środkowego i Zachodniego (Jasiulewicz, 1990; Jażewicz, 2011), województwa kujawsko-pomorksiego (Szymańska i Matczak, 1998; Gierańczyk i Krajewska, 2017), a w centralnej - Mazowsza (Potrykowska, 2002). Inne regiony były badane stosunkowo rzadziej.

Kolejna grupa zagadnień podejmowanych w geograficznych badaniach nad migracjami wewnętrznymi po 1990 r. dotyczy redystrybucji ludności na obszarach metropolitalnych i w aglomeracjach. Najbardziej szczegółowym studium identyfikacyjnym z tego okresu pozostaje monografia dotycząca rejestrowanych przepływów w aglomeracji warszawskiej w 1995 r., bazująca na międzygminnej i międzydzielnicowej macierzy zameldowań i wymeldowań wraz z podziałem na 5-letnie kategorie wieku i płci (Potrykowska i Śleszyński, 1999). Natomiast w całym kraju badania tego typu prowadzili Szymańska i Biegańska (2011), Śleszyński (2013b), Winiarczyk-Raźniak i Raźniak (2012) oraz Kurek et al. (2020). Stosunkowo dużo jest przykładów badań dla największych aglomeracji, m.in. 
Warszawy (Korcelli, 1993; Mantey, 2013; Śleszyński, 2019), Krakowa (Więcław-Michniewska, 2004; Kurek et al., 2015), Trójmiasta (Działek, 2015), Bydgoszczy i Torunia (Szymańska i Hołowiecka, 2000b), Łodzi (Dzieciuchowicz, 1995) oraz konurbacji katowickiej (Szajnowska-Wysocka, 1999). Natomiast bardzo mało jest badań dotyczących migracji międzymiejskich (Śleszyński, 2011b). Poza badaniami dziennej mobilności cyklicznej (np. Dziadek, 1997), brakuje też prac nt. stałych migracji transgranicznych.

Osobną grupę stanowią badania migracji w mikroskali, najczęściej na obszarze miast. Badania takie podejmowano m.in. dla Łodzi (Michalski i Szafrańska, 2000; Ogrodowczyk i Wolaniuk, 2014), Wrocławia (Kozieł, 1996), Poznania (Marcinowicz, 2000) i Wałcza (Szymańska, 2005). Kierunkiem badawczym, który dobrze rozwinął się w polskiej geografii miast, a który jest ściśle powiązany z migracjami stałymi, są badania gentryfikacji, czyli procesów „uszlachetniania” społecznego obszarów w mieście i jego otoczeniu, zwłaszcza poprzez selektywny napływ mieszkańców o określonych cechach (np. Polko, 2011; Górczyńska, 2015).

Zdecydowana większość geograficznych badań migracji wewnętrznych ma charakter identyfikacyjny i opisowy, poszukujący różnego rodzaju prawidłowości przestrzennych, a rzadziej wyjaśniający. Przy tym najbardziej powszechne jest wykorzystanie danych z Banku Danych Lokalnych (Regionalnych) GUS. Szczególnie mało jest prac wiążących kierunki i natężenie migracji z bardziej ogólnymi procesami w przestrzeni społeczno-ekonomicznej, jak np. wspomniana już klasyczna praca Zborowskiego nt. modeli urbanizacyjnych (2005) oraz bardziej szczegółowych odnośnie kierunków migracji, uwzględniających np. macierze międzygminne (Huk, Kozieł, Potrykowska, Śleszyński). Badania na podstawie typowych metod socjologicznych, np. ankiety i kwestionariusza są sporadyczne (Skoczek, 2012; Mantey, 2013; Kurek et al., 2014).

\section{Migracje zewnętrzne (emigracja i imigracja zagraniczna)}

Badania geograficzne migracji zagranicznych posiadają szeroki wymiar. Z jednej strony odnoszą się zarówno do migracji zagranicznych w Polsce, jak i wybranych aspektów mobilności w Europie i na innych kontynentach, z drugiej natomiast przedmiotem ich zainteresowań jest emigracja, napływ ludności (imigracja), w mniejszym stopniu także powroty z zagranicy (reemigracja), w kontekście kierunków tych przepływów, skali, przyczyn oraz skutków międzynarodowych ruchów ludności. Wyraźnie wyodrębniają się również opracowania dotyczące oceny źródeł danych, prognozowania ruchów migracyjnych oraz ujęcia modelowe mobilności przestrzennej. Analizy geograficzne dobrze oddają także określone przemiany w zakresie międzynarodowej mobilności w ostatnich dekadach, zwłaszcza w Polsce, ale także w innych krajach europejskich. Prace geograficzne nawiązują ponadto do praktyki społeczno-gospodarczej, co najbardziej widoczne jest w opracowaniach odnoszących się do polityk migracyjnych, realizowanych na różnych poziomach (regionalny, krajowy, europejski) i w różnych krajach.

Spośród poszczególnych form mobilności zagranicznej w Polsce najszerszą uwagę poświęca się emigracji, zwłaszcza w okresach przełomowych dla mobilności Polaków. Znajdują się tutaj publikacje dotyczące emigracji w okresie PRL (Runge, 1991), w tym konsekwentnie rozwijana i uszczegóławiana seria monogrfaii Eberhardta (2000, 2006, 2010, 2017), wyjazdów w okresie transformacji na początku lat 90. XX w. (Długosz, 2007) 
oraz po wejściu Polski do Unii Europejskiej w 2004 r. (Zborowski i Gałka, 2008; Śleszyński, 2013b; Gałka, 2017, 2018), przy czym najbardziej interesująca dla badaczy jest skala tych przemieszczeń oraz ich kierunki (np. Jończy i Rokita-Poskart, 2016). W przypadku nowych krajów migracji poakcesyjnej Polaków, analizy geografów dotyczą niemal wyłącznie Wielkiej Brytanii (Gałka, 2012), w mniejszym stopniu Irlandii (Szmytkowska, 2011; Matykowski, 2012). W tym kontekście już na początku transformacji Korcelli (1994) wskazywał, że po „otwarciu” granic migracje międzynarodowe i wewnętrzne w Polsce są od siebie silnie współzależne, gdyż mają wspólne ekonomiczne podłoże. W okresie przedakcesyjnym powstały także prace poświęcone prognozowaniu skali emigracji z Polski po akcesji oraz ich konsekwencjom w aspekcie demograficznym, ekonomicznym i społecznym (Kupiszewski, 1998; było to pokłosiem dużej konferencji zorganizowanej na ten temat - Korcelli, 1998).

Geograficzne analizy na temat imigracji do Polski powstawały już na początku lat 90. ubiegłego wieku, a więc w okresie, gdy napływ cudzoziemców nie stanowił jeszcze zjawiska istotnego w sensie ilościowym (Szymańska, 1994a). Dopiero splot dwóch czynników - sytuacji geopolitycznej na Ukrainie i luki podażowej na polskim rynku pracy spowodował, że znacznie wzrosła skala imigracji, zwłaszcza z Ukrainy, przyczyniając się do wzrostu zainteresowania tą tematyką. W pierwszych analizach dotyczących wpływu emigracji ukraińskiej, zwłaszcza na rynek pracy, wskazywano m.in. na efekt słabszego wzrostu przeciętnej płacy w niektórych branżach (wskutek napływu „tańszej” siły roboczej). Ponadto imigranci ukraińscy mają zdecydowanie bardziej rozproszony model lokalizacji przestrzennej (Górny i Śleszyński, 2019). Skłania to do wniosku, że ten typ migracji może mieć większe znaczenie na lokalnych rynkach pracy. Samo zjawisko wpisuje się w wypełnianie powstającej luki podażowej na rynku pracy, w związku z emigracją obywateli Polski za granicę i niekorzystnymi trendami w zakresie ruchu naturalnego (Grzelak-Kostulska, 2013; Nowotnik, 2013; Brunarska et al., 2016). Ostatnio podejmowane jest też w kontekście transformacji modelu migracyjnego Polski z emigracyjnego na imigracyjny (Solga i Kubiciel-Lodzińska, 2017).

Zdecydowana większość prac geograficznych z tego zakresu, podejmowana zazwyczaj w ramach bardziej kompleksowych opracowań ludnościowych, społeczno-gospodarczych itp. (w tym podręczników) opiera się na „oficjalnej” statystyce, zatem do wyników ilościowych nie należy przywiązywać specjalnie dużej uwagi. Bardziej wartościowe są natomiast ustalenia pewnych prawidłowości przestrzennych i regionalnych. Prace tego typu są wciąż kontynuowane (Śleszyński 2006a; Gałka i Warych-Juras, 2009; Jakóbczyk-Gryszkiewicz, 2016, 2018; Górny i Śleszyński, 2019), lecz wydaje się, że problematyka imigracji nie jest w badaniach geograficznych szeroko podejmowana.

Stosunkowo wąski zakres mają natomiast geograficzne badania nad migracją powrotną. W zasadzie odnoszą się one jedynie do regionalnego wymiaru migracji powrotnych i w głównej mierze dotyczą województwa opolskiego (Heffner, 1999b; Solga, 2014) lub całego Górnego Śląska (Heffner, 1998).

Nowym wątkiem w badaniach prowadzonych przez geografów jest utylitarny wymiar problematyki migracyjnej. Kwestie dotyczące mobilności na płaszczyźnie europejskiej odnoszą się niemal wyłącznie do dwóch zagadnień, tj. różnych aspektów migracji wewnętrznych w Europie i do polityki migracyjnej. Polityka migracyjna realizowana na poziomie UE lub poszczególnych krajów europejskich, stała się przedmiotem zainteresowań w badaniach geograficznych dopiero w ostatnich latach. Mimo to powstają prace, które mają szczególnie istotne znaczenie z punktu widzenia kształtowania się polskiej polityki migra- 
cyjnej. Są to analizy polityk imigracyjnych, w tym zwłaszcza integracyjnych, w krajach mających bogate i długie doświadczenie w przyjmowaniu cudzoziemców, głównie Niemiec i Wielkiej Brytanii (Jaczewska, 2013). Dotyczy to polskiej polityki migracyjnej, analizowanej zarówno w szerszym aspekcie jako elementu systemu polityk publicznych oraz określonych wyzwań w tym zakresie (Korcelli, 2004; Kupiszewski, 2007; Solga, 2015a; Heffner i Solga, 2019; Solga i Tereszkiewicz, 2020), jak i węższym - nawiązującym do polityki imigracyjnej, w tym zwłaszcza integracyjnej (Gibki, 2011).

Z kolei problematyka migracji wewnątrzunijnych jest nie tylko stosunkowo często podejmowana, ale także ma wielowymiarowy charakter. Przedmiotem analiz są w tym przypadku zarówno uwarunkowania przemieszczeń ludnościowych w UE (Janicki i Kubik-Komar, 2007), jak również określone trendy migracyjne w Europie (Bijak i Kupiszewski, 2013). W ostatnich latach szczególny nacisk kładzie się na kwestie migracji zastępczych, analizowanych w kontekście przemian demograficznych, tj. spadku liczebności europejskiej populacji i jej starzenia się (Bijak et al., 2013; Kupiszewski, 2013).

\section{Badania terytoriów zagranicznych}

Geografowie dość aktywnie podejmują badania migracji w innych, także dość odległych krajach. Wiąże się to zwłaszcza z działalnością Instytutu Studiów Regionalnych i Globalnych UW (dawniej Instytutu Krajów Rozwijających Się). W bibliografii zidentyfikowano około 100 tego typu prac, z czego blisko połowa pochodzi od autorów warszawskich. Najwięcej opracowań dotyczy kręgu latynoskiego i latynoamerykańskiego (np. Skoczek, 1994; Skoczek i Lisocka-Jaegermann, 2015), w tym m.in. Ekwadoru (Bonasewicz, 1998), Karaibów (Lisocka-Jaegerman, 2005), czy Meksyku (Skoczek, 2013).

Drugim poważnym obszarem zainteresowań polskich geografów jest Europa Wschodnia, w tym Rosja i inne kraje powstałe po upadku ZSRR, bądź leżące przed 1989 r. w orbicie jego wpływów. Należy tu wymienić przede wszystkim liczne i często cytowane studia Eberhardta z pogranicza geografii migracji i geografii etnicznej oraz geodemografii i geopolityki, podsumowane w jego monumentalnej pracy (559 s.) wydanej w Stanach Zjednoczonych (Eberhardt, 2003). Z ciekawszych prac tego autora warto też przytoczyć studium dotyczące konsekwencji migracyjnych rozpadu Związku Radzieckiego (Eberhardt, 1998a). Problematyką Rosji, w tym zwłaszcza wyludniania się Syberii, zajmuje się Wites (2007). Badania innych autorów dotyczą m.in. Litwy (Kowalski, 1997) i Ukrainy (Gentile i Marcińczak, 2012).

Z badaniami międzynarodowymi ściśle powiązane są studia historyczne i polonijne. Do najciekawszych osiągnięć należy „Atlas Polonii Francuskiej” (Atlas of Polish Emigration in France), wydany przez Stowarzyszenie Wspólnota Polska i Uniwersytet Łódzki (Marszał, 2001). Zawiera on unikalne informacje o rozmieszczeniu Polaków w różnych okresach na przestrzeni niemal całego XX w. Z kolei żmudne kwerendy archiwalne Kowalskiego przyczyniły się do poważnych odkryć, zmieniających poglądy na kolonizację obszarów dzisiejszej Republiki Południowej Afryki, gdyż dowiedziono stosunkowo wysokiego udziału ludności polskiej (Kowalski, 2006, 2012a).

Najrzadziej spotykanym, ale niezwykle ważnym z poznawczego i metodologicznego punktu widzenia jest udział geografów (względnie osób zatrudnionych w ośrodkach geograficznych) w badaniach globalnych lub dotyczących większych całości polityczno- 
-gospodarczych świata. Studia tego typu zazwyczaj muszą być prowadzone przez zespoły badawcze składające się z naukowców z różnych krajów. W pierwszej kolejności wymienić tutaj należy działalność przywoływanego wielokrotnie Kupiszewskiego (IGiPZ PAN, CEFMR), którego duża część aktywności naukowej była poświęcona przede wszystkim krajom Unii Europejskiej i szerzej Europy. Z inicjatywy jego oraz znanego geodemografa brytyjskiego Phila Reesa, powstał cykl wieloautorskich opracowań (w zespołach byli też inni badacze z Polski) nt. migracji wewnętrznych, przygotowany dla 18 krajów Europy, w tym Polski (Kupiszewski et al., 1998b). Było to największe tego typu studium dla Europy, jak też prawdopodobnie na świecie, wykonane według jednolitej metodologii na najniższym możliwym poziomie przestrzennym. Podsumowanie części badań (10 krajów) znalazło się w monografii Reesa i Kupiszewskiego (1999).

Warto też wspomnieć o działalności Potrykowskiej (IGiPZ PAN, GUS) w Komisji Ludności i Środowiska Międzynarodowej Unii Geograficznej (w tym przewodniczenie komisji). W Polsce została wydana zbiorowa praca, dotycząca związków rozwoju gospodarczego i ludnościowego oraz migracji ze środowiskiem naturalnym w różnych częściach świata (Potrykowska, 2005). Do tematyki środowiskowej w kontekście odpływu migracyjnego nawiązują m.in. prace dotyczące wpływu zdarzeń powodziowych we Wrocławiu (Grygierczyk, 1998).

\section{Badania wpływu migracji na rozwój regionalny i lokalny}

Badania geograficzne posiadają bardzo istotny wkład w rozwój analiz dotyczących wpływu procesów demograficzno-migracyjnych na przemiany na poziomie lokalnym i regionalnym. Kluczowa jest tu kwestia przestrzennej redystrybucji ludności, związanej z równoważeniem się rynków pracy, tj. podaży i popytu na pracę. Wpływ ten rozważany jest z perspektywy procesu koncentracji - będącego efektem napływu ludności i zasobów pracy na dany obszar, jak i dekoncentracji - spowodowanej odpływem mieszkańców. Pierwszy obszar obejmuje głównie badania napływu migracyjnego ludności do stref podmiejskich i skutki tego procesu w postaci zmian struktur demograficznych oraz wzrostu natężenia dojazdów do pracy, ale też różnego rodzaju kosztów zewnętrznych, związanych z ułomnością polskiej niekontrolowanej urbanizacji i silnym chaosem przestrzennym (Kowalewski et al., 2018). Z kolei odpływ migracyjny z terenów wiejskich interpretowano w kontekście modernizacji (w tym transformacji po 1989 r.) oraz ułomnej (opóźnionej, niedokończonej) urbanizacji, tj. odchodzenia od rolniczego charakteru lokalnych i regionalnych rynków pracy bez odpowiedniej migracji ze wsi do miast przy równoczesnym braku powstawania miejsc pracy poza rolnictwem (Dziewoński i Korcelli, 1981; Heffner i Kamińska, 2011; Rosner, 2014; Heffner, 2019).

Zagadnienie koncentracji potencjału społeczno-gospodarczego i ludzkiego w obrębie aglomeracji miejskich wskutek migracji analizuje się także z perspektywy procesu metropolizacji. Proces ten oznacza dalszą marginalizację nie tylko regionów peryferyjnych, ale i miast z ich zapleczami znajdującymi się na niższych szczeblach hierarchii administracyjno-osadniczej, głównie poprzez „wymywanie” ( „wypłukiwanie” ) i przejmowanie ich funkcji (Smętkowski, 2003).

Obszar drugi (dekoncentracja ludności) analizowany jest z perspektywy konsekwencji emigracji zarówno wewnętrznych, jak i zagranicznych oraz ich skutków dla obszarów 
odpływowych. Badania te wykazały, że odpływ migracyjny charakteryzuje zwłaszcza najmniejsze miejscowości, przyczyniając się do deformacji ich struktur demograficznych, w tym do silnego postarzania oraz do zmian w strukturze płci populacji (Kurek, 2007; Wiśniewski et al., 2016). Odpływ ludzi młodych lub z wyższym wykształceniem może prowadzić do stagnacji technologicznej, a tym samym modernizacji gospodarek lokalnych. Dodatkowe niebezpieczeństwo wyludniania wynika z faktu, że ludność pozostała na miejscu odznacza się obniżoną aktywnością społeczną i niskim stopniem aktywności gospodarczej. Tym samym obszary dotychczas znajdujące się w recesji, na skutek emigracji jeszcze bardziej mogą pogłębiać swój kryzys. Ponadto zwrócono uwagę, że odpływ migracyjny na ogół przyczynia się do spadku poziomu bezrobocia (Jończy, 2006), lecz jednocześnie powoduje zmniejszenie się potencjalnych zasobów pracy i zmianę ich rozkładu przestrzennego. Selektywny odpływ migracyjny przyczynia się do braku podaży w pewnych zawodach niszowych lub o szczególnych kwalifikacjach (Szukalski, 2015). Regularne migracje zagraniczne mogą być jednak czynnikiem tworzącym nowe miejsca zatrudnienia. Na lokalnym rynku pracy tworzy się bowiem szeroka infrastruktura usługowa obsługująca migrantów, tj. firmy rekrutujące pracowników, rozliczające podatki, realizujące transfery pieniężne oraz świadczące usługi transportowe.

Najwięcej badań dotyczących wpływu migracji na rozwój na poziomie regionalnym dotyczy Śląska Opolskiego (Heffner, 2018; Heffner i Solga, 1999, 2014; Rauziński, 1999; Jończy 2003, 2010, 2015; Heffner, 2006b, 2012), w mniejszym stopniu Podlasia (Cieślińska, 1992; Hirszfeld i Kaczmarczyk, 2000), Podhala i Podkarpacia (Bieńkowska et al., 2010). W badaniach tych szczególne miejsce zajmuje jednak województwo opolskie, co wynika z faktu, że obszar ten był przez cały okres powojenny wyraźnym regionem odpływowym i problemy depopulacyjne obserwowano tam od dawna. Głównie na bazie doświadczeń tego obszaru wypracowano koncepcję regionu emigracyjnego rozumianego jako strukturę regionalną, której rozwój jest ściśle powiązany z konsekwencjami demograficznymi, społecznymi, gospodarczymi i kulturowymi ujemnego salda migracji (Heffner i Rauziński, 2003; Solga, 2013).

W regionie opolskim monitorowane i badane są różnorodne zagadnienia związane z migracjami (np. dynamika zmian migracyjnych, przyczyny utrzymującej się emigracji z regionu, wewnętrzny odpływu ludzi młodych, mechanizmy kształtujące te zjawiska, napływ z zagranicy), lecz problematyka wpływu migracji na rozwój regionalny lub lokalny, z uwzględnieniem konsekwencji o charakterze ekonomicznym, demograficznym, infrastrukturalnym oraz społeczno-kulturowym, jest przedmiotem szerokich zainteresowań. W badaniach tego typu zwraca się uwagę przede wszystkim na demograficzne konsekwencje depopulacji (Dybowska, 2013; Rauziński, 2016), szczególnie na peryferyjnych obszarach wiejskich (Heffner i Kamińska, 2011).

Zmniejszanie się pod wpływem migracji potencjału ludnościowego regionu opolskiego przez wielu badaczy uznane zostało jako katastrofalne dla regionalnych zasobów pracy, wewnętrznego rynku regionu oraz perspektyw rozwoju gospodarczego (Solga, 2015b). Szczególne miejsce zajmują badania lokalnych efektów popytowych powodowanych transferami finansowymi z zagranicy. Dochód uzyskiwany przez migrantów za granicą jest częściowo transferowany do kraju i wydawany w miejscach pochodzenia migrantów, co może znacznie pobudzać koniunkturę oraz generować znaczące wpływy do budżetu państwa z tytułu podatku od towarów i usług (Jończy i Rokita-Poskart, 2012a, 2012b). Z drugiej strony wykazano, że migracje mogą obniżać stan budżetów gminnych, gdyż osoby pracujące za gra- 
nicą nie płacą podatków w kraju. Jednocześnie coraz więcej samorządów zwraca uwagę na wzrastające obciążenia finansowe ze strony wydatków na opiekę socjalną samotnych członków rodzin migrantów (głównie starszych rodziców) (Solga, 2013). Ryzyko niestabilności finansów samorządowych jest jednym z najważniejszych czynników, które wpływają na silniejsze akcentowanie potrzeb polityki demograficznej w strategiach rozwoju, zarówno na obszarach wiejskich, jak też w „kurczących się" miastach (Bartosiewicz, 2016).

Większość badaczy i praktyków zajmujących się oceną wymiaru regionalnych migracji, jak i ich przyczyn oraz skutków zwraca uwagę, że bez kompleksowych i długookresowych działań obejmujących obie te sfery, przeciwdziałanie negatywnym trendom demograficznym staje się bardzo trudne (Heffner et al., 2019; Wiśniewski et al., 2020). Stąd procesy demograficzne, w tym szeroko rozumiane migracje ludności, stały się dużym wyzwaniem dla polityki regionalnej oraz dla tworzenia podstaw i utrzymywania rozwoju społeczno-gospodarczego w strukturach lokalnych (miastach i obszarach wiejskich). Z jednej strony podejmowane działania mają charakter dostosowawczy i są odpowiedzią na zmniejszanie się (często słabo ewidencjonowane) potencjału populacji regionalnej oraz pogarszanie struktury demograficznej populacji (Zdrojewski, 2000). Z drugiej strony, proponowane inicjatywy zmierzają do wywołania efektów istotnie zmieniających uwarunkowania bilansu ludnościowego regionów oraz tworzących je struktur lokalnych - miast, gmin wiejskich, powiatów. Zazwyczaj polegają one na podnoszeniu atrakcyjności miejsca zamieszkania, przyciąganiu nowych mieszkańców (tworzenie warunków stabilizujących napływ wewnętrzny i imigrację), ograniczaniu zjawiska „wykruszania się” migrantów wahadłowych i krótkoterminowych, zachęcaniu do powrotu i ułatwianiu podejmowania decyzji przez reemigrantów oraz stabilizowaniu warunków pracy i zamieszkania przyjeżdżających do regionu imigrantów (Kubiciel-Lodzińska, 2011).

\section{Podsumowanie}

Jak wspomniano we wstępie, literatura dotycząca geograficznych badań migracyjnych jest bardzo bogata i zróżnicowana. Wśród około 750 pozycji bibliograficznych (w niniejszym tekście zacytowano 180 publikacji (25\%) pochodzi z Instytutu Geografii i Przestrzennego Zagospodarowania PAN (głównie Kupiszewski - ok. 100 pozycji oraz Korcelli, Potrykowska, Śleszyński i in.). Kolejne znaczące ośrodki badawcze to Instytut Studiów Regionalnych i Globalnych UW (Skoczek, Lisocka-Jaegermann i in.), Instytut Geografii i Gospodarki Przestrzennej UJ (Zborowski, Gałka), Instytut Geografii UP w Krakowie (Długosz, Kurek) oraz Instytut Geografii UMK w Toruniu (Szymańska). Jednak największą liczbę badań wypracowały osoby związane ze Śląskiem Opolskim (Heffner, Jończy, Rauziński, Rokita-Poskart, Solga, Szczygielski i in.), co czyni ten region zdecydowanie najlepiej przebadanym pod względem migracji w Polsce. Ale dorobku tego nie można wpisać jedynie na konto geografii, jako że badania co do natury „geograficzne” (przedmiot i problem badań, metodologia) były wykonywane zarówno instytucjonalnie w jednostkach ekonomicznych, jak też w dużej mierze przez ekonomistów.

Wśród wszystkich publikacji około 70\% wydano w Polsce w języku polskim, co spowodowało, że wiele z interesujących osiągnięć nie weszło do obiegu międzynarodowego. Dotyczy to zwłaszcza ważnego okresu transformacji politycznej i społeczno-gospodarczej. Po wejściu Polski do UE wymiana wiedzy i wykorzystanie prac geograficznych są lepsze. 
W podejmowanych badaniach przeważa nurt empiryczny, związany ze statystyczno-kartograficzną identyfikacją oraz opisem obserwowanych zjawisk i procesów. Identyfikacja ta bazuje najczęściej na wtórnych danych GUS (rejestracja bieżąca zameldowań i wymeldowań), przyjmowanych jeszcze do niedawna dość bezkrytycznie przez większość geografów. Najmniej prac dotyczy modelowania i wkładu w teorię, co w stosunku do lat 70. XX w., będących szczytowym okresem polskich geograficznych badań nad migracjami (jak też szerzej, geograficznych badań nad procesami ludnościowymi i osadniczymi), stanowi wyraźny regres. Tak więc bardzo duża na tle innych dyscyplin liczba prac, identyfikowanych jako geograficzne, nie oznacza automatycznego postępu koncepcyjno-teoretycznego. Natomiast na korzyść względem badań typowo statystycznych i demograficznych, a poniekąd socjologicznych i ekonomicznych, przemawia bardzo dobre „wyczucie przestrzenne” i znajomość lokalnych czynników, pozwalających unikać nadmiernego uśredniania do zbyt heterogenicznych agregatów terytorialnych, np. województw, prowadzących do zbyt ogólnych efektów poznawczych w innych dyscyplinach, zwłaszcza w ekonomii. Również częściowe korzystanie z metodologii badań społecznych o charakterze ilościowym oraz jakościowym umożliwia prowadzenie pogłębionych studiów (zwłaszcza w układach regionalnych i lokalnych), dotyczących istoty zachowań migracyjnych, mechanizmów oddziaływań czynników środowiskowych na ludność (selektywność), jak również niektórych elementów procesów decyzyjnych (motywy, preferencje).

Tym niemniej w okresie po 1989 r. w geograficznych badaniach migracji można wskazać kilka grup zagadnień, które można traktować jako osiągnięcia naukowe wykraczające poza przedmiotowo-problemowe ramy dyscypliny i mające bardziej uniwersalny charakter. Po drugie, da się wskazać pewną liczbę wyników, mających znaczenie metodologiczne ważne głównie dla samej dyscypliny. Po trzecie, w geografii po 1989 r. powstała dość pokaźna liczba obszernych monografii dotyczących fundamentalnych wydarzeń z historii kraju i regionu, mających duże znaczenie identyfikacyjne i faktograficzne. Tak więc, do głównych i najbardziej oryginalnych osiągnięć geograficznych badań po 1989 r. należy zaliczyć:

- wieloregionalne modelowanie dynamiki zmian ludności z uwzględnieniem złożoności procesów migracji (Korcelli, Kupiszewski), które jest też osiągnięciem typowo „demograficznym" i dobrym przykładem badań prowadzonych z różnych pozycji dyscyplinarnych, ale wspólnych metodologicznych;

- historyczne badania mobilności i dynamiki ludności na tle warunków narodowościowo-etnicznych, m.in. wywołanych I i II wojną światową (Eberhardt);

- szczególnie wyczerpujące i kompleksowe rozpoznanie specyficznego regionu migracyjnego Śląska Opolskiego (Dybowska, Heffner, Jończy, Kubiciel-Lodzińska, Rauziński, Rokita-Poskart, Solga, Szczygielski i in.), które również z powodzeniem przełamuje podział dyscyplinarny geografii i ekonomii, korzystnie zbliżając te dyscypliny badawcze;

- kompleksowe i syntetyczne rozpoznanie zjawisk i procesów ludnościowo-migracyjnych w Polsce w całym XX w. (Eberhardt, Gawryszewski);

- badania roli migracji i szerzej mobilności w rozwoju stref podmiejskich i obszarów metropolitalnych (Gałka, Kurek, Mantey, Potrykowska, Szymańska, Śleszyński, Zborowski), w tym złożonych zespołów osadniczych (Kłosowski, Runge, Szajnowska-Wysocka); 
- migracyjne badania terytoriów zagranicznych, zwłaszcza Ameryki Łacińskiej (Bonasewicz, Lisowska-Jaegermann, Skoczek i in.), a także przełomowe badania historycznych migracji Polaków do południowej Afryki (Kowalski);

- szczegółowe badania związków migracji z lokalnym i regionalnym rozwojem społeczno-gospodarczym (Długosz, Jażewicz, Jończy, Heffner, Solga, Śleszyński, Wites);

- wkład w klasyfikacje, typologie, delimitacje i wskaźniki migracji oraz zastosowanie wskaźników migracyjnych w tego typu procedurach w szerszym kontekście dyscyplinarnym (Długosz, Kupiszewski, Kurek, Śleszyński);

- empiryczne wykazanie przeszacowań i niedoszacowań stanów ludności wskutek nierejestrowanych migracji w różnych układach przestrzennych (Dybowska, Heffner, Jończy, Śleszyński);

- wkład w teorię urbanizacji (Zborowski), w tym relacje pomiędzy migracjami i systemem osadniczym (Korcelli).

Jeśli chodzi o ewolucję badań migracji prowadzonych w ośrodkach geograficznych w Polsce, to najbardziej charakterystyczna jest, jak się wydaje, coraz silniejsza integracja międzydyscyplinowa i coraz mocniejsze, odważniejsze wkraczanie geografów na pola dotychczas zarezerwowane dla innych dyscyplin naukowych. Powodowane jest to niewątpliwie wzrostem mobilności ludności, co ma silnie przestrzenny, „geograficzny” wymiar, tj. uwarunkowania i skutki. Kierunek odwrotny, tj. badania nie-geografów dotychczasowych typowych pól badawczych geografii, jest też zresztą zauważalny, ale ze względu na potrzebny często specjalistyczny warsztat badawczy, związany z umiejętnościami analizy przestrzennej, znajomości metod kartograficznych, czy użycia narzędzi Systemów Informacji Geograficznej (GIS) i „drążenia danych” (data mining) wciąż takich badań jest mało. Pojawiające się analizy, zwłaszcza ekonomiczne, są też często zbyt powierzchowne (np. dla poziomu województw, czy w anachronicznym już podziale miasto-wieś według sztywnych definicji administracyjnych).

Natomiast pod względem liczbowym aktywność publikacyjna jest na mniej więcej podobnym poziomie (ryc. 1). Poza wyjątkowymi latami 1998 i 2012, związanymi zwłaszcza z działalnością Kupiszewskiego, w pozostałych okresach liczba prac utrzymywała się na dość zbliżonym poziomie 20-30 prac rocznie. Głównym językiem był polski (około 70\%), a wśród języków obcych dominował angielski, a pozostałe to m.in. hiszpański i francuski.

Jeśli chodzi o przyszłość rozwoju geograficznych badań migracyjnych w Polsce, to można wskazać na wiążące się z tym zarówno zagrożenia, jak i szanse. Wśród tych pierwszych z pewnością największą barierą pozostaną braki w wiarygodności „oficjalnych” źródeł statystycznych. Stają się one coraz bardziej poważne, uniemożliwiając powstanie wiarygodnych i bardziej ogólnych modeli rozwoju struktur przestrzennych. W tym kontekście prace geograficzne, podobnie zresztą jak typowo demograficzne i ekonomiczne, wyróżniają się niestety zbyt mało krytycznym zaufaniem do źródeł statystycznych. Jednak to co jest aktualnie słabością, może stać się swego rodzaju katalizatorem dla szybszych przemian metodologicznych i metodyczno-statystycznych. Duże nadzieje w rozwoju badań nad przestrzennymi zjawiskami migracyjnymi należy bowiem wiązać z doskonaleniem narzędzi data mining oraz gromadzeniem przez różne podmioty coraz obszerniejszych danych lokalizacyjnych (sieci komórkowe, GPS i in.), pozwalających coraz dokładniej i wiarygodniej rejestrować rzeczywistą mobilność ludzką w przestrzeni geograficznej. Niewątpliwie, w najbliższym czasie należy spodziewać się także prac związanych z wpływem pandemii COVID-19, w tym tzw. lockdownu, na zmiany w mobilności. 


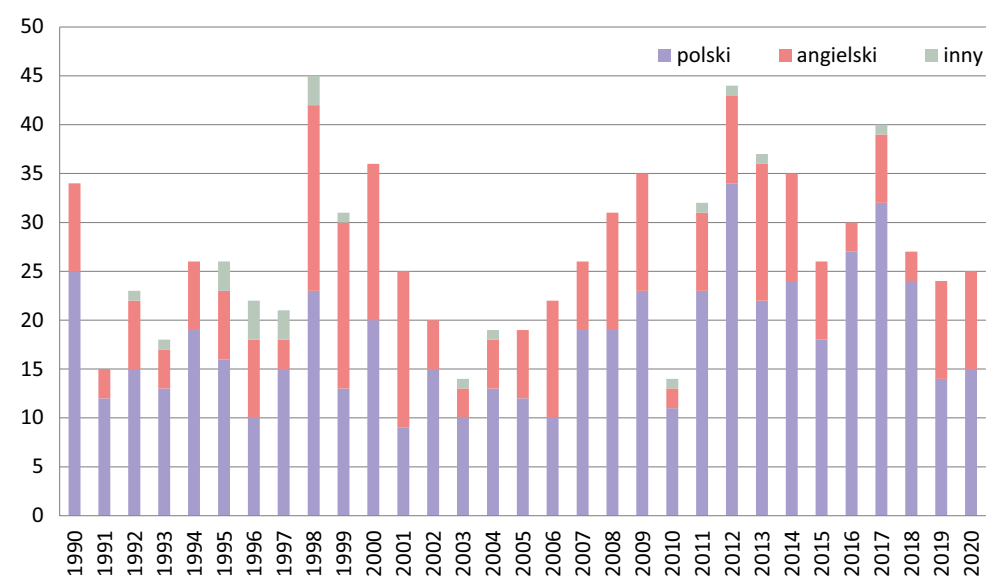

Ryc. 1. Liczba wydanych prac i jej struktura pod względem języka publikacji (1990-2020) Number of papers published and their structure in terms of the language of publication Źródło: Śleszyński et al. (2018, s. 194), uzupełnione na podstawie aktualizacji z ośrodków geograficznych nadesłanych przez członków Komisji Geografii Osadnictwa i Ludności PTG (Krzysztofik - Sosnowiec, Mularczyk

- Kielce, Szmytkie - Wrocław, Wesołowska - Lublin) oraz kwerendy w Publish or Perish/Google Scholar.

\section{Piśmiennictwo}

Bartosiewicz, B. (2016). Polityka rozwoju lokalnego w kurczących się małych miastach. Prace Naukowe Uniwersytetu Ekonomicznego we Wrocławiu, 418, 22-31. https://doi.org/10.15611/pn.2016.418.02

Bell, M., Charles-Edwards, E., Kupiszewska, D., Kupiszewski, M., Stillwell, J., \& Zhu, Y. (2015). Internal migration data around the World: Assessing contemporary practice. Population, Space and Place, 21(1), 1-17. https://doi.org/10.1002/psp.1848

Bieńkowska, D., Ulasiński, C., \& Szymańska, J. (red.). (2010). Trajektorie migracyjne województwa podkarpackiego. Kraków: Centrum Doradztwa Strategicznego.

Bijak, J., \& Kupiszewski, M. (2013). International migration trends in Europe prior to 2002. W: M. Kupiszewski (red.), International migration and the future of populations and labour force resources in Europe (s. 57-74). Dordrecht: Springer.

Bijak, J., Kupiszewska, D., Kupiszewski, M., \& Saczuk, K. (2013). Population ageing, population decline and replacement migration in Europe. W: M. Kupiszewski (red.), International migration and the future of populations and labour force resources in Europe (s. 243-265). Dordrecht: Springer.

Bonasewicz, A. (1998). Migraciones internas en el Ecuador en los ańos 1950-1990. W: G. Mertins, M. Skoczek (red.), Migraciones de la poblacion latinoamericana y sus efectos socio-economicos (s. 29-42). Warszawa: PTSL/WGiSR UW.

Brunarska, Z., Kindler, M., Szulecka, M., \& Toruńczyk-Ruiz, S. (2016). Ukrainian migration to Poland: A "Local" Mobility? W: O. Fedyuk, \& M. Kindler (red.), Ukrainian Migration to the European Union. Lessons from Migration Studies (s. 115-132). Glasgow-Warszawa: Springer Open. https://doi.org/10.1007/978-3-319-41776-9

Churski, P., Czyż, T., \& Spychała-Szyszka, H. (1996). Weryfikacja makroregionu poznańskiego w świetle migracji studentów. W: T. Czyż (red.), Podstawy regionalizacji geograficznej (s. 69-95). Poznań: Bogucki Wyd. Naukowe. 
Cieślińska, B. (1992). Przyczyny i skutki wyjazdów zagranicznych Polaków (w świetle badania ankietowego mieszkańców północno-wschodniej Polski). Pogranicze. Studia Społeczne, 2, 153-170.

Czapiewski, K. (2007). Less favoured areas and migrations in Poland - are there any relations?. W: Less favoured areas for agriculture and rural areas. Collection of papers of international conference (s. 116-128). Praha-Jihlava: Vyzkumny ustav zemedelske ekonomiky.

Długosz, Z. (1991). Migracje ludności w miastach wojewódzkich w świetle zmian administracyjnych w Polsce z 1975 r. Zeszyty Naukowe UJ. Prace Geograficzne, 84, 55-64.

Długosz, Z. (1992). Typologia miast Polski w świetle wybranych parametrów migracji ludności. Rozprawy Habilitacyjne UJ, 241. Kraków: Uniwersytet Jagielloński.

Długosz, Z. (2003). Migracje w województwie małopolskim w latach 1986-1998. Folia Geographica-Oeconomica, 31-32, 51-60.

Długosz, Z. (2006). Migration of population in big polish cites as compared to smaller cities and town in the light of selected parameters of the migration process. Bulletin of Geography. Socio-economic Series, 6, 33-50.

Długosz, Z. (2007). Wybrane aspekty stałej emigracji ludności z Polski za granicę po 1989 roku. Czasopismo Geograficzne, 78(1-2), 3-22.

Długosz, Z., \& Kurek, S. (1998). Migration of the population of the Carpathian provinces in 1986-1995 in light of selected migration parametres. Polish Population Review, 13, 131-138.

Dolińska, A., Jończy, R., \& Śleszyński, P. (2020). Migracje pomaturalne w województwie dolnoślqskim wobec depopulacji regionu i wymogów zrównoważonego rozwoju społeczno-gospodarczego. Wrocław: Wydawnictwo Uniwersytetu Ekonomicznego we Wrocławiu.

Dybowska, J. (2013). Przemiany demograficzne w regionie o nasilonej migracji zagranicznej na przykładzie województwa opolskiego. Opole: Wydawnictwo Uniwersytetu Opolskiego.

Dziadek, S. (1997). Wpływ ruchu granicznego i migracji transgranicznych na społeczne koszty na przykładzie gmin województw: bielskiego i katowickiego. W: J. Kitowski (red.), Problemy regionalne współpracy transgranicznej (s. 131-142). Rzeszów: UMCS, Komisja Geografii Komunikacji PTG, KPZK PAN.

Działek, J. (2015). Powiązania migracyjne i procesy suburbanizacji rezydencjonalnej. W: R. Guzik (red.), Czynniki i ograniczenia rozwoju miast województwa pomorskiego - badanie ciążeń, powiqzań, migracji i dostępności komunikacyjnej (s. 41-66). Gdańsk: Urząd Marszałkowski Województwa Pomorskiego.

Dzieciuchowicz, J. (1995). Determinanty demograficzne i społeczno-ekonomiczne redystrybucji przestrzennej ludności aglomeracji miejskich. Przykład aglomeracji łódzkiej. Łódź: Wydawnictwo Uniwersytetu Łódzkiego.

Dziewoński, K., \& Korcelli, P. (red.). (1981). Studia nad migracjami i przemianami systemu osadniczego w Polsce, Prace Geograficzne, 140. Wrocław: Zakład Narodowy im. Ossolińskich, IGiPZ PAN.

Dziewoński, K., Gawryszewski, A., Iwanicka-Lyrowa, E., Jelonek, A., Jerczyński, M., \& Węcławowicz, G. (1977). Rozmieszczenie i migracje ludności a system osadniczy Polski Ludowej, Prace Geograficzne, 117. Warszawa: IGiPZ PAN.

Eberhardt, P. (1989). Regiony wyludniajgce się w Polsce, Prace Geograficzne, 148. Warszawa: IGiPZ PAN.

Eberhardt, P. (1998a). Konsekwencje migracyjne rozpadu Związku Radzieckiego dla Polski. W: P. Korcelli (red.), Przemiany w zakresie migracji ludności jako konsekwencja przystapienia Polski do Unii Europejskiej (s. 123-153), Biuletyn KPZK PAN, 184. Warszawa: KPZK PAN.

Eberhardt, P. (2000). Przemieszczenia ludności na terytorium Polski spowodowane Il wojnq światowq, Dokumentacja Geograficzna, 15. Warszawa: IGiPZ PAN. 
Eberhardt, P. (2003). Ethnic groups and population changes in twentieth-century Central-Eastern Europe. History, data and analysis. Armonk, New York, London: M.E. Sharpe.

Eberhardt, P. (2006). Political migrations in Poland 1939-1948, Bibliotheca Europae Orientalis, 25, Seria Didactica, 3. Warszawa: Studium Europy Wschodniej UW.

Eberhardt, P. (2010). Migracje polityczne na ziemiach polskich (1939-1950). Poznań: Instytut Zachodni.

Eberhardt, P. (2017). Political migrations in Poland in the period of World War II. New York: Nova Science Publishers.

Gałka, J. (2012). Areas of concentration and an analysis of factors affecting the distribution of Polish immigrants in Great Britain since Poland's accession to the European Union. Prace Geograficzne, 130, 29-41.

Gałka, J. (2017). Wpływ permanentnych migracji zagranicznych na zmiany regionalnych układów zaludnienia w Polsce. Studia Ekonomiczne, 309, 95-108.

Gałka, J. (2018). Rola poakcesyjnych migracji zagranicznych w zmianach przestrzennych układów zaludnienia w Polsce w latach 2004-2012. Studia Miejskie, 29, 45-60. https://doi.org/10.25167/sm2018.029.03

Gałka, J., \& Warych-Juras, A. (2009). Ocena rozmiarów i kierunku napływu obcokrajowców (imigrantów) do polskich miast, w tym ich cech społeczno-demograficznych. W: A. Zborowski (red.), Demograficzne i społeczne uwarunkowania rewitalizacji miast w Polsce (s. 61-92). Kraków: Instytut Rozwoju Miast.

Gawryszewski, A. (1974). Zwiq̨zki przestrzenne między migracjami stałymi i dojazdami do pracy oraz czynniki przemieszczeń ludności. Prace Geograficzne, 109. Warszawa: IG PAN.

Gawryszewski, A. (1989). Przestrzenna ruchliwość ludności Polski, 1952-1985, Prace Habilitacyjne. Warszawa: IGiPZ PAN, Ossolineum.

Gawryszewski, A. (1992). Spatial population mobility in Poland, 1952-1985. Geographia Polonica, 59, 69-77.

Gawryszewski, A. (1997). Przestrzenna ruchliwość ludności Polski. Bibliografia (lata 1896-1990), Dokumentacja Geograficzna, 7. Warszawa: IGiPZ PAN.

Gawryszewski, A. (2005). Ludność Polski w XX wieku, Monografie, 5. Warszawa: IGiPZ PAN.

Gawryszewski, A. (red.). (1972). Modele migracji, Przegląd Zagranicznej Literatury Geograficznej, 3-4. Warszawa: IG PAN.

Gentile, M., \& Marcińczak, S. (2012). No more work for Stakhanov: migrants and stayers in the depopulating Donbas, Ukraine. Urban Geography, 33(3), 401-419. https://doi.org/10.2747/0272-3638.33.3.401

Gibki, B. (2011). Imigranci w mieście. Nowe wyzwania dla polityki integracyjnej. W: A. Richling, \& M. Fuhrmann (red.), Geograficzne spotkania w drodze. Krok trzeci (s. 95-105). Warszawa: WGiSR UW.

Gierańczyk, W., \& Krajewska, M. (2017). Zmiany zachowań migracyjnych w województwie kujawsko-pomorskim. Wiadomości Statystyczne, 10, 69-84.

Górczyńska, M. (2015). Polityka mieszkaniowa jako narzędzie różnicowania społecznego w Paryżu. Przegląd Geograficzny, 87(2), 225-253. https://doi.org/10.7163/PrzG.2015.2.2

Górny, A., \& Śleszyński, P. (2019). Exploring the spatial concentration of foreign employment in Poland under the simplified procedure. Geographia Polonica, 92(3), 331-345.

https://doi.org/10.7163/GPol.0152 
Grabowska, M., \& Jończy, R. (red.). (2013). Edukacyjny, zarobkowy i definitywny exodus młodzieży z obszarów peryferyjnych Dolnego Śląska i jego skutki dla zrównoważonego rozwoju regionalnego. Tom 1 i 2 . Wrocław: Uniwersytet Ekonomiczny we Wrocławiu.

Grygierczyk, M. (1998). Zamiary migracyjne mieszkańców obszarów objętych klęską powodzi. W: T. Sołdra-Gwiżdż (red.), Społeczne skutki powodzi w lipcu 1997 roku w województwie opolskim (s. 49-54). Zeszyty Odrzańskie. Seria Nowa, 17. Opole: PIN - Instytut Śląski w Opolu.

Grzelak-Kostulska, E. (2013). Cudzoziemcy w Polsce w opinii studentów: ewolucja postaw i poglądów. W: J. Balicki, \& M. Chamarczuk (red.), Wokół problematyki migracyjnej: kultura przyjęcia (s. 206-216). Tom 7. Warszawa: Ministerstwo Rozwoju Regionalnego.

Heffner, K. (1998). Górny Śląsk. Imigracja jako następstwo procesów emigracji. W: D. Szymańska (red.), Ruchliwość przestrzenna ludności w okresie przemian ustrojowych (s. 99-119). Toruń: Wydawnictwo UMK.

Heffner, K. (1999). The Return of Emigrants from Germany to Upper Silesia: Reality and Prospects. W: K. Iglicka, \& K. Sword (red.), The Challange of East-West Migration for Poland (s. 168-205). London-New York: Macmillan.

Heffner, K. (2006). Migracje zagraniczne jako składowa rynków pracy w regionach migracyjnych. W: A. Rączaszek (red.), Sześćdziesiq̨t lat polityki społecznej w Polsce. Księga pamiq̨tkowa na jubileusz osiemdziesięciolecia prof. zw. dr hab. Lucyny Frąckiewicz (s. 259-272). Katowice: Wydawnictwo Akademii Ekonomicznej w Katowicach.

Heffner, K. (2012). Migracje a rozwój regionu. Znaczenie procesów migracyjnych dla rozwoju regionów w Polsce. W: R. Rauziński, \& T. Sołdra-Gwiżdż (red.), Społeczeństwo Ślq̨ska Opolskiego 1945-2011-2035 - aspekty spoteczne, demograficzne i rynku pracy (s. 79-91). Opole-Warszawa: PIN - Instytut Śląski w Opolu, Urząd Marszałkowski Województwa Opolskiego.

Heffner, K. (2018). Migracje a rozwój regionu opolskiego. Znaczenie procesów migracyjnych w kontekście regionalnej konkurencji. Studia Ślq̨skie, 83, 163-184.

Heffner, K. (2019). Pozarolnicza działalność na obszarach wiejskich. W: M. Halamska, M. Stanny, \& J. Wilkin (red.), Ciqgłość i zmiana Sto lat rozwoju polskiej wsi (s. 947-976). Warszawa: IRWiR PAN.

Heffner, K., \& Kamińska, W. (red.). (2011). Obszary wiejskie. Wielofunkcyjność - migracje - nowe wizje rozwoju, Studia KPZK PAN, 133. Warszawa: KPZK PAN.

Heffner, K., \& Rauziński, R. (2003). Region migracyjny (wybrane aspekty demograficzne, społeczne i gospodarcze na przykładzie Ślqska Opolskiego), Studia i Monografie, 152. Opole: Oficyna Wydawnicza Politechniki Opolskiej.

Heffner, K., \& Solga, B. (1999). Praca w RFN i migracje polsko-niemieckie a rozwój regionalny Ślqaska Opolskiego, Stowarzyszenie Instytut Śląski. Opole: PIN - Instytut Śląski w Opolu.

Heffner, K., \& Solga, B. (2008). Polityka migracyjna jako narzędzie monitorowania i kreowania przepływów ludnościowych. Aspekt krajowej i wspólnotowej polityki migracyjnej. W: K. Malik (red.), Monitorowanie rozwoju regionu. Wymiar społeczny, gospodarczy i środowiskowy (s. 215-226). Opole: Politechnika Opolska. Wydział Zarządzania i Inżynierii Produkcji, Samorząd Województwa Opolskiego, Komitet Nauk o Pracy i Polityce Społecznej PAN.

Heffner, K., \& Solga, B. (2013). Features of a migration region - an analysis using the example of the Opolskie Voivodship. Bulletin of Geography. Socio-economic Series, 20, 43-58.

https://doi.org/10.2478/bog-2013-0010

Heffner, K., \& Solga, B. (2014). Ewolucja procesów migracyjnych na Śląsku Opolskim w kontekście europejskim: identyfikacja głównych tendencji na tle przemian demograficznych. Studia Śląskie, 75, 71-87. 
Heffner, K., \& Solga, B. (2019). Challenges to the state policytowards migration processes in Poland. Studia z Geografii Politycznej i Historycznej, 8, 107-116. https://doi.org/10.18778/2300-0562.08.06

Heffner, K., Klemens, B. \& Solga, B. (2019). Challenges of Regional Development in the Context of Population Ageing. Analysis Based on the Example of Opolskie Voivodeship. Sustainability, 11, 5207. https://doi.org/10.3390/su11195207

Herbst, M. (2015). Regionalne stopy zwrotu z inwestycji w edukację w kontekście migracji międzyregionalnych. Studia Regionalne i Lokalne, 1(59), 5-20. https://doi.org/10.7366/1509499515901

Hirszfeld, Z., \& Kaczmarczyk, P. (2000). Współczesne migracje zagraniczne ludności Podlasia, Prace Migracyjne, 30. Warszawa: Instytut Studiów Społecznych UW.

Horolets, A., Lesińska, M., \& Okólski, M. (2018). Raport o stanie badań nad migracjami w Polsce po 1989 roku. Warszawa: Komitet Badań nad Migracjami PAN.

Huk, J. (1991). Wyznaczanie regionów migracyjnych w ujęciu systemowym. Acta Universitatis Wratislaviensis, Studia Geograficzne, 57, 1-160.

Huk, J. (2004). Migracje ludności na Dolnym Śląsku w latach 1989-1998. Kierunki i efektywność. Czasopismo Geograficzne, 75(1-2), 33-64.

Jaczewska, B. (2013). Migration Management in the European Union. Immigration Policy in Germany and the United Kingdom. W: Narratives of Ethnic Identity, Migration and Politics, A Multidisciplinary Perspective (s. 21-35). Kraków: Księgarnia Akademicka.

Jagielski, A. (1974). Geografia ludności. Warszawa: PWN.

Jagielski, A. (1994). Geografia ludności i migracje wewnętrzne. W: Rozwój demografii polskiej 1918-1993 (s. 87-102). Warszawa: GUS.

Jakóbczyk-Gryszkiewicz, J. (2016). Imigranci spoza UE w Polsce, Łodzi i regionie łódzkim. Acta Universitatis Lodziensis. Folia Geographica Socio-Oeconomica, 26(4), 135-153.

https://doi.org/10.18778/1508-1117.26.08

Jakóbczyk-Gryszkiewicz, J. (2018). Czy imigracja jest szansą dla wyludniających się polskich miast? Wybrane rodzaje ruchów migracyjnych. Przegląd Geograficzny, 90(2), 291-308. https://doi.org/10.7163/PrzG.2018.2.5

Janc, K., Czapiewski, K.t., \& Bajerski, A. (2012). Where the brains are, where the brains move: education, skilled migration and human capital in Poland. W: P. Churski (red.), Contemporary issues in Polish geography (s. 179-200). Poznań: Bogucki Wyd. Naukowe.

Janicki, W. \& Kubik-Komar, A. (2007). Determinanty międzyregionalnych migracji ludności na obszarze Unii Europejskiej w latach 1986-1994. Studia Demograficzne, 1(151), 111-136.

Janicki, W. (2007). Przegląd teorii migracji ludności. Annales UMCS, 52, 285-304.

Janicki, W. (2015). Migracje kompensacyjne jako czynnik wzrostu obszarów peryferyjnych. Rola ukrytego kapitału ludzkiego. Lublin: UMCS.

Jasiulewicz, M. (1990). Procesy migracji ludności wiejskiej Pomorza Zachodniego (na przykładzie woj. koszalińskiego). W: A. Stasiak (red.), Migracje ze wsi do miast (s. 130-150), Studia KPZK PAN, 96. Warszawa: KPZK PAN.

Jażewicz, I. (2011). Ruchliwość przestrzenna ludności woj. pomorskiego w okresie transformacji systemowej. W: M. Stanny (red.), Przemiany demograficzno-społeczne na Pomorzu. Ujęcie przestrzenne (s. 131-141). Koszalin: Wydawnictwo Politechniki Koszalińskiej.

Jończy, R. (2003). Migracje zarobkowe ludności autochtonicznej z województwa opolskiego. Studium ekonomicznych determinant i konsekwencji. Opole: Wydawnictwo Uniwersytetu Opolskiego.

Jończy, R. (2006). Wpływ migracji zagranicznych na dysharmonię rozwoju województwa opolskiego (ze szczególnym uwzględnieniem rynku pracy). Opole: Wojewódzki Urząd Pracy w Opolu, Urząd Marszałkowski Województwa Opolskiego, Uniwersytet Opolski. 
Jończy, R. (2010). Migracje zagraniczne z obszarów wiejskich województwa opolskiego po akcesji Polski do Unii Europejskiej. Wybrane aspekty ekonomiczne i demograficzne. Opole-Wrocław: Instytut Śląski.

Jończy, R. (2012). Nierejestrowane wyludnienie wsi w kontekście możliwości wykorzystania oficjalnych danych statystycznych i spisowych. Wnioski z badań w województwie opolskim. Studia Ekonomiczne, 103, 70-90.

Jończy, R. (2015). Ekonomiczno-społeczne skutki współczesnych migracji w wymiarze regionalnym - na przykładzie regionu opolskiego. Warszawa-Wrocław-Opole: KBnM PAN, Uniwersytet Ekonomiczny we Wrocławiu, Wojewódzki Urząd Pracy w Opolu.

Jończy, R., \& Rokita-Poskart, D. (2012a). Wpływ zagranicznych migracji zarobkowych na sytuacje społeczno-demograficznq województwa opolskiego. Opole: Obserwatorium Integracji Społecznej Regionalnego Ośrodka Polityki Społecznej w Opolu.

Jończy, R., \& Rokita-Poskart, D. (2012b). Wybrane fiskalne konsekwencje migracji zarobkowej oraz związanego z nią transferu dochodów (na przykładzie województwa opolskiego). Barometr Regionalny, 2(28), 49-56.

Jończy, R., \& Rokita-Poskart, D. (2016). Zmiany głównych kierunków migracji zagranicznych w latach 2007-2014 (na przykładzie studentów opolskiego ośrodka akademickiego). Studia Ekonomiczne, 292, 80-88.

Kłosowski, F., \& Runge, J. (2000). Migration of the Population of Katowice Province in the Period 1977-1997. Polish Population Review, 17, 110-118.

Kłosowski, F., \& Runge, J. (2010). Migracje ludności w miastach województwa śląskiego w latach 1977-2006. Górnoślquskie Studia Socjologiczne. Seria Nowa, 1, 83-92.

Korcelli, P. (1982). Migration and urban change. International Regional Science Review, 7(2), 193-216. Korcelli, P. (1992a). Regional population projections: A multiple base-point approach. Geographia Polonica, 59, 21-32.

Korcelli, P. (1992b). International Migrations in Europe: Polish Perspectives for the 1990s. International Migration Review, 26(2), 292-304.

Korcelli, P. (1993). Migration and demographic change in the region of Warsaw. Geographia Polonica, 61, 95-101.

Korcelli, P. (1994). On interrelations between internal and international migration. Innovation, 9(2), 151-163.

Korcelli, P. (1997). Alternatywne projekcje zmian demograficznych i migracji w aglomeracjach miejskich. W: P. Korcelli (red.), Aglomeracje miejskie w procesie transformacji: V (s. 5-21), Zeszyty IGiPZ PAN, 45. Warszawa: IGiPZ PAN.

Korcelli, P. (2000). Inter-metropolitan competition in East-Central Europe and the evolving position of Warsaw. W: P. Friedrich, \& S. Jutila (red.), Policies of regional competition (s. 165-178), Schriften zur oeffentlichen Verwaltung und oeffentlichen Wirtschaft, 161. Baden-Baden: Nomos Verlagsgesellschaft.

Korcelli, P. (2004). Migracje kompensacyjne a dylematy polityki migracyjnej. Studia Regionalne i Lokalne, 3, 61-73.

Korcelli, P. (red.). (1998). Przemiany w zakresie migracji ludności jako konsekwencja przystapienia Polski do Unii Europejskiej, Biuletyn KPZK PAN, 184. Warszawa: KPZK PAN.

Kosiński, L. (1960). Pochodzenie terytorialne ludności Ziem Zachodnich w 1950 r., Dokumentacja Geograficzna, 2. Warszawa: IGiPZ PAN.

Kowalewski, A., Markowski, T., \& Śleszyński, P. (red.). (2018). Studia nad chaosem przestrzennym, Studia KPZK PAN, 182(1-3). Warszawa: KPZK PAN. 
Kowalski, M. (1997). Problem miasta Wisaginia (Yisaginias) na Litwie jako przykład skutków migracji transgranicznych. W: J. Kitowski (red.), Społeczne koszty migracji transgranicznych (s. 387-400), Rozprawy i Monografie Wydziału Ekonomicznego UMCS. Filia w Rzeszowie, 12. Rzeszów: Komisja Geografii Komunikacji Polskiego Towarzystwa Geograficznego w Warszawie, Wydział Ekonomiczny Filii Uniwersytetu Marii Curie-Skłodowskiej w Rzeszowie.

Kowalski, M. (2006). Polish Boer families. The influence of early Polish immigration on Boer families. Familia, 43(2), 38-46.

Kowalski, M. (2012). Imigranci z Rzeczpospolitej Obojga Narodów w początkowej fazie europejskiego osadnictwa w Kolonii Przylądkowej. Przegląd Geograficzny, 84(2), 279-312. https://doi.org/10.7163/PrzG.2012.2.6

Kowalski, M., \& Śleszyński, P. (2010). Migracje Polaków do Niemiec w świetle częstotliwości występowania najbardziej popularnych polskich nazwisk. Przegląd Zachodni, 66(2), 115-130.

Kozieł, R. (1996). Czasoprzestrzenna zmienność migracji wewnątrzmiejskich we Wrocławiu. Acta Universitatis Wratislaviensis, 1904, Seria B. Geografia Spoteczna i Ekonomiczna, 14, 45-55.

Kubiciel-Lodzińska, S. (2011). Zatrudnienie cudzoziemców w województwie opolskim jako konsekwencja przemian następujących na regionalnym rynku pracy. Stan obecny i perspektywy. Barometr Regionalny. Analizy i Prognozy, 4(26), 31-37.

Kupiszewski, M. (1998). Czy na podstawie doświadczeń innych krajów można przewidywać zmiany migracji międzynarodowych po przyjęciu Polski do Unii Europejskiej? W: P. Korcelli (red.), Przemiany w zakresie migracji ludności jako konsekwencja przystapienia Polski do Unii Europejskiej (s. 67-78), Biuletyn KPZK PAN, 184. Warszawa: KPZK PAN.

Kupiszewski, M. (2002). Modelowanie dynamiki przemian ludności w warunkach wzrostu znaczenia migracji międzynarodowych, Prace Geograficzne, 181. Warszawa: IGiPZ PAN.

Kupiszewski, M. (red.). (2007). Demographic developments, labour market and international migration in Poland - policy challenges, CEFMR Working Paper, 3. Warsaw: Central European Forum for Migration Research.

Kupiszewski, M. (red.). (2013). International migration and the future of populations and labour force resources in Europe, The Springer Series on Demographic Methods and Population Analysis. Dordrecht-Heidelberg-New York-London: Springer.

Kupiszewski, M., Durham, H., \& Rees, P. (1998). Internal migration and urban change in Poland. European Journal of Population, 14, 265-290. https://www.jstor.org/stable/20164035

Kurek, S., Wójtowicz, M., \& Gałka, J. (2020). Functional Urban Areas in Poland. Demographic Trends and Migration Patterns. Cham: Springer.

Kurek, S. (2006). Migration of the elderly in Poland in 1991-2001. Bulletin of Geography. Socio-economic Series, 5, 161-172. https://doi.org/10.1515/2480

Kurek, S., Gałka, J., \& Wójtowicz, M. (2014). Wpływ suburbanizacji na przemiany wybranych struktur demograficznych i powiqzań funkcjonalno-przestrzennych w Krakowskim Obszarze Metropolitalnym. Kraków: Wydawnictwo Naukowe Uniwersytetu Pedagogicznego.

Kurek, S., Wójtowicz, M., \& Gałka, J. (2015). The changing role of migration and natural increase in suburban population growth - an example from non-capital post-socialist city (Krakow Metropolitan Area in Poland). Moravian Geographical Reports, 23(4), 59-70. https://doi.org/10.1515/mgr-2015-0024

Kusiński, W. (1994). Migracje jako przedmiot zainteresowań badawczych polskich geografów. W: S. Liszewski (red.), Geografia osadnictwa i ludności w niepodległej Polsce. Lata 1918-1993 (s. 37-54), t. 2. Łódź: Komisja Geografii Osadnictwa i Ludności PTG. 
Kwiatek-Sołtys, A. (2006). Migration attractiveness of small towns in the Małopolska Province. Bulletin of Geography. Socio-economic Series, 5, 155-160.

Lisocka-Jaegermann, B. (2005). Migracje kobiet karaibskich. Migracje i Społeczeństwo, 10, 149-176.

Mantey, D. (2013). Pułapka suburbanizacji, czyli o planach migracyjnych młodych piaseczan. Przeglad Geograficzny, 85(2), 271-289. https://doi.org/10.7163/PrzG.2013.2.6

Marszał, T. (red.). (2001). Atlas of Polish Emigration in France (Atlas Polonii Francuskiej). Łódź: Stowarzyszenie Wspólnota Polska, Uniwersytet Łódzki.

Matykowski, R. (2012). Polish economic migrants in Ireland, 2004-2007. Geographia Polonica, 85(1), 33-43. https://doi.org/GPol.2012.1.3

Michalski, W., \& Szafrańska, E. (2000). Wewnątrzmiejskie migracje stałe mieszkańców Łodzi w 1997 roku. W: D. Szymańska (red.), Procesy i formy ruchliwości przestrzennej ludności w okresie przemian ustrojowych (s. 201-215). Toruń: UMK.

Nowotnik, D. (2013). Imigracje zagraniczne na stałe do Polski. Prace Komisji Geografii Przemysłu PTG, 22, 161-181.

Ogrodowczyk, A., \& Wolaniuk, A. (2014). Przemieszczenia ludności Łodzi wymuszone gentryfikacja. W: A. Wolaniuk (red.), Centra i peryferie w okresie transformacji ustrojowej (s. 273-288). Łódź: Wyd. Uniwersytetu Łódzkiego.

Polko, A. (2011). Gentryfikacja na obszarach małych miast oraz gmin wiejskich sqqsiadujacych z dużq aglomeracjq (s. 17-28), Studia KPZK PAN, 126. Warszawa: KPZK PAN.

Potrykowska, A. (2002). Zróżnicowanie przestrzenne migracji wewnątrzregionalnych w regionie miejskim Warszawy. W: G. Węcławowicz (red.), Warszawa jako przedmiot badań w geografii społeczno-ekonomicznej (s. 103-114), Prace Geograficzne, 184. Warszawa: IGiPZ PAN.

Potrykowska, A. (2003). Przestrzenne zróżnicowanie procesu starzenia się ludności i migracji osób w starszym wieku w Polsce. Przeglad Geograficzny, 75(1), 41-59.

Potrykowska, A. (red.). (2005). Population, environment and development, Prace Geograficzne, 202. Warszawa: IGiPZ PAN.

Potrykowska, A., \& Śleszyński, P. (1999). Migracje wewnętrzne w Warszawie i województwie warszawskim, Atlas Warszawy, 7. Warszawa: IGiPZ PAN.

Pytel, S. (2017). Migracje emerytów w Polsce - czynniki, kierunki, konsekwencje. Katowice: Wyd. Uniwersytetu Śląskiego.

Rauziński, R. (1999). Współczesne migracje zagraniczne na Śląsku Opolskim. Aspekty demograficzne i społeczne. Opole: Politechnika Opolska.

Rauziński, R. (2016). Migracje zagraniczne a rozwój regionalny i lokalny (przykład Śląska Opolskiego). W: A. Górny, P. Kaczmarczyk, \& M. Lesińska (red.), Transformacje. Przewodnik po zmianach spoteczno-ekonomicznych w Polsce (s. 225-228). Warszawa: Scholar.

Rauziński, R., \& Szczygielski, K. (2016). Ludność, zatrudnienie, migracje wśród ludności wiejskiej Śląska opolskiego w latach 1995-2017-2035. Studia Obszarów Wiejskich, 41, 245-262.

https://doi.org/10.7163/SOW.41.16

Rees, P., \& Kupiszewski, M. (red.). (1999). Internal migration and regional population dynamics in Europe: a synthesis, 52. Strasbourg: Council of Europe Publishing.

Rees, P., Bell, M., Kupiszewski, M., Kupiszewska, D., Ueffing, P., Bernard, A., Charles-Edwards, E., \& Stillwell, J. (2017). The impact of internal migration on population redistribution: an international comparison. Population Space and Place, 23(6), 1-22. https://doi.org/10.1002/psp.2036

Rokita-Poskart, D. (2016). Konsekwencje wewnętrznych migracji edukacyjnych w gospodarczym pejzażu miasta akademickiego (na przykładzie opolskiego ośrodka akademickiego). Studia Migracyjne-Przeglad Polonijny, 42, 3(161), 205-222. 
Rosner, A. (2010). Rola ruchu naturalnego i migracyjnego w procesie zmian przestrzennego rozkładu gęstości zaludnienia obszarów wiejskich. Wieś i Rolnictwo, 4(149), 42-56.

Rosner, A. (2014). Migracje wewnętrzne i ich związek z przestrzennym zróżnicowaniem rozwoju społeczno-gospodarczego wsi. Wieś i Rolnictwo, 1(162), 63-80.

Runge, J. (1991). Emigracja zagraniczna ludności województwa katowickiego w latach 1976-1988. Czasopismo Geograficzne, 1-2, 98-101.

Runge, J. (1998). Ruchliwość przestrzenna ludności województwa katowickiego na tle przemian społeczno-ekonomicznych regionu. W: D. Szymańska (red.), Ruchliwość przestrzenna ludności w okresie przemian ustrojowych (s. 215-229). Toruń: Wyd. UMK.

Rykiel, Z. (1985). Zagadnienia regionalnych systemów osadniczych, Studia KPZK PAN, 88. Warszawa: KPZK PAN.

Skoczek, M. (1994). Migracje ludności wiejskiej w Ameryce Łacińskiej a gospodarka lokalna. Prace i Studia Geograficzne, 15, 119-129.

Skoczek, M. (2012). Nowe cechy mobilności przestrzennej młodych Polaków - na podstawie wypowiedzi studentów Uniwersytetu Warszawskiego. W: M. Buchowski, \& J. Schmidt (red.), Imigranci: między integracjq a izolacjq (s. 151-167).Warszawa: Wydawnictwo Nauka i Innowacje.

Skoczek, M. (2013). Zmiany zachowań migracyjnych ludności indiańskiej Meksyku na przełomie XX i XXI wieku. Przypadek mieszkańców Regionu Mazahua. W: M. Skoczek (red.), Zmiany społeczno-gospodarcze w regionach tubylczych Meksyku i ich percepcja przez mieszkańców. Przypadek Regionu Mazahua (s. 91-112). Warszawa: WGSR UW.

Skoczek, M., \& Lisocka-Jaegermann, B. (2015). Migracje ludności jako czynnik zmian społeczno-gospodarczych w Ameryce Łacińskiej. Prace i Studia Geograficzne, 59, 71-86.

Smętkowski, M. (2003). Polaryzacja procesów rozwoju w regionie metropolitalnym Warszawy. W: I. Jażdżewska (red.), Funkcje metropolitalne i ich rola w organizacji przestrzeni (s. 135-145). Łódź: Katedra Geografii Miast i Turyzmu UŁ, Łódzkie Towarzystwo Naukowe.

Solga, B. (2013a). Miejsce i znaczenie migracji zagranicznych w rozwoju regionalnym. Opole: Politechnika Opolska.

Solga, B. (2013b). Migracje powrotne w województwie opolskim. Charakter zjawiska i jego znaczenie dla rozwoju regionu. Barometr Regionalny, 11(3), 99-109.

Solga, B. (2014). The Importance of International Return Migration in the Rural Development. Studia Regionalia, 39, 101-112.

Solga, B. (2015a). Polityka migracyjna jako element polskiej polityki społecznej. Wieś i Rolnictwo, 3, 133-147.

Solga, B. (2015b). Einfluss der Auslandsmigration auf die Entwicklung der Regionen in Polen. W: G. Jelitto-Piechulik (red.), Grenzüberquerungen und Migrationsbewegungen. Fremdheits- und Integrationserfahrungen in der österreichischen, deutschen, schweizerischen und polnischen Literatur und Lebenswelt (s. 47-59). Wien: LIT-Verlag.

Solga, B., \& Kubiciel, S. (2017). Poland: immigration instead of emigration. Transformation of the mobility model. W: K. Soliman (red.), Vision 2020: Sustainable Economic Development, Innovation Management and Global Growth (s. 797-811), I-IX. Madrid: IBIMA Conference.

Solga, B., \& Tereszkiewicz, F. (2020). Challenges of Poland's Migration Policy from the Perspective of the Experiences of Selected European Union Countries. European Research Studies Journal, XXIII, Special Issue 2, 435-451. https://doi.org/10.35808/ersj/1834

Stanny, M. (2000). Wpływ migracji definitywnych na proces koncentracji ludności w Polsce w latach 1976-1995. W: D. Szymańska (red.), Procesy i formy ruchliwości przestrzennej w okresie przemian ustrojowych (s. 109-118). Toruń: Wydawnictwo UMK. 
Stillwell, J., Bell, M., Ueffing, P., Daras, K., Charles-Edwards, E., Kupiszewski, M., \& Kupiszewska, D. (2016). Internal migration around the world: comparing distance travelled and its frictional effect. Environment and Planning A, 48, 1657-1675. https://doi.org/10.1177/0308518X16643963

Szajnowska-Wysocka, A. (1999). Zachowania przestrzenne ludności konurbacji górnoślq̨skiej. Synteza badawcza. Katowice: Wydawnictwo UŚ.

Szmytkowska, M. (2011). Polish Migrants in Urban Space of Dublin. Bulletin of Geography, Socio-economic Series, 16, 139-152. https://doi.org/10.1515/v10089-011-0019-4

Szukalski, P. (2015). Demograficzno-społeczne konsekwencje depopulacji w województwie łódzkim. W: Problemy społeczne. Polityka społeczna w regionie łódzkim (s. 3-20), 15. Łódź: Regionalne Centrum Polityki Społecznej w Łodzi.

Szymańska, D. (1994). Imigracja zagraniczna w warunkach przemian ustrojowych po 1989 r. Biuletyn Pomorze Nadwiślańskie, 8, 72-81.

Szymańska, D. (red.). (2000). Procesy i formy ruchliwości przestrzennej ludności w okresie przemian ustrojowych. Toruń: Wydawnictwo UMK.

Szymańska, D., \& Biegańska, J. (2011). Obszary podmiejskie dużych miast w Polsce w świetle migracji stałych. W: M. Soja, A Zborowski (red.), Człowiek w przestrzeni zurbanizowanej (s. 83-98). Kraków: IGiGP Uniwersytetu Jagiellońskiego.

Szymańska, D., \& Hołowiecka, B. (2000a). Migracje stałe do i z miast średniej wielkości w okresie przemian ustrojowych. W: D. Szymańska (red.), Procesy i formy ruchliwości przestrzennej ludności w okresie przemian ustrojowych (s. 243-254). Toruń: Wydawnictwo UMK.

Szymańska, D., \& Hołowiecka, B. (2000b). Ruch wędrówkowy ludności i jego zasięg oddziaływania na przykładzie miasta Bydgoszczy i Torunia. W: D. Szymańska (red.), Procesy i formy ruchliwości przestrzennej ludności w okresie przemian ustrojowych (s. 217-222). Toruń: Wydawnictwo UMK.

Szymańska, D., \& Matczak, A. (1998). Region miejski Brodnicy w świetle migracji stałych. W: S. Ciok, \& J. Łoboda (red.), Przekształcenia regionalnych struktur funkcjonalno-przestrzennych (s. 79-91), Acta Universitatis Wratislaviensis, nr 2048, Studia Geograficzne, 69. Wrocław: Wydawnictwo Uniwersytetu Wrocławskiego.

Szymańska, W. (2005). Migracje wewnątrzmiejskie w średnich miastach Pomorza na przykładzie Wałcza. W: J. Czerwiński (red.), Problemy demograficzne $w$ regionach nadmorskich $w$ procesie integracji europejskiej (s. 131-138), Biuletyn Informacyjny Polskiego Towarzystwa Demograficznego, 28/B. Warszawa, PTD.

Śleszyński, P. (2005). Różnice liczby ludności ujawnione w Narodowym Spisie Powszechnym 2002. Przegląd Geograficzny, 77(2), 193-212.

Śleszyński, P. (2006). Imigracja do Polski w latach 1989-2002 na podstawie wyników NSP 2002. Studia Demograficzne, 149, 82-88.

Śleszyński, P. (2011a). Oszacowanie rzeczywistej liczby ludności gmin województwa mazowieckiego z wykorzystaniem danych ZUS. Studia Demograficzne, 2(160), 35-57.

Śleszyński, P. (2011b). Social linkages. W: T. Komornicki, P. Siłka (red.), Functional linkages between Polish metropolises (s. 65-80), Studia Regionalia, 29. Warszawa: KPZK PAN.

Śleszyński, P. (2013). Migracje na Obszarze Metropolitalnym Warszawy: uwarunkowania i wnioski dla polityki miejskiej i przestrzennej. Samorzqd Terytorialny, 11, 45-61.

Śleszyński, P. (2015). The linkages and the functional hierarchy of cities and towns of Eastern Poland in the light of migrations registered in 2009. Economic and Regional Studies, 8(4), 28-44.

https://doi.org/10.22004/ag.econ.265217

Śleszyński, P. (2018). Migracje wewnętrzne. W: A. Potrykowska (red.), Sytuacja demograficzna Polski. Raport 2017-2018 (s. 154-195). Warszawa: Rządowa Rada Ludnościowa. 
Śleszyński, P. (2019). Directions of migration registered in the Warsaw Metropolitan Area. W: Ł. Skoczylas, E. Smolarkiewicz (red.), Internal migrations in Poland, Migration-Ethnicity-Nation: Studies in Culture, Society and Politics (s. 97-117), 9. Berlin: Peter Lang.

Śleszyński, P. (2020). Koncepcja nowego wskaźnika atrakcyjności migracyjnej i jego zastosowania. Czasopismo Geograficzne, 91(1-2), 37-58.

Śleszyński, P., Heffner, K., Solga, B., \& Wiśniewski, R. (2018). Perspektywa geografii i studiów regionalnych w badaniach nad migracjami. W: A. Horolets, M. Lesińska, M. Okólski, Raport o stanie badań nad migracjami w Polsce po 1989 roku (s. 174-210). Warszawa: Komited Badań nad Migracjami PAN.

Śleszyński, P., Herbst, M., Komornicki, T., Wiśniewski, R., Bański, J., Biedka, W., Celińska-Janowicz, D., Degórski, M., Goch, K., Goliszek, S., Grabowska, M., Mazur, M., Olechnicka, A., Otmianowski, M., Piotrowski, F., Płoszaj, A., Rok, J., Smętkowski, M., Stępień, M., Śliwowski, P., Więckowski, M., \& Wojnar, K. (2020). Studia nad obszarami problemowymi w Polsce, Studia Komitetu Przestrzennego Zagospodarowania Kraju PAN. Cykl Monografii, 7/199. Warszawa: Polska Akademia Nauk, Komitet Przestrzennego Zagospodarowania Kraju.

Wesołowska, M. (2011). Migracje ludności i ich skutki w regionie peryferyjnym (na przykładzie województwa lubelskiego). Barometr Regionalny. Analizy i Prognozy, 3(25), 59-65.

Więcław-Michniewska, J. (2004). Migracje mieszkańców osiedli suburbialnych w Krakowie. W: J. Słodczyk, D. Rajchel (red.), Przemiany demograficzne i jakość życia ludności miast (s. 163-170). Opole: Uniwersytet Opolski.

Winiarczyk-Raźniak, A., \& Raźniak, P. (2012). Migracje wewnętrzne ludności w polskich obszarach metropolitalnych u progu XXI wieku, Prace Monograficzne Uniwersytetu Pedagogicznego, 604. Kraków: Wydawnictwo Naukowe Uniwersytetu Pedagogicznego.

Wiśniewski, R., Mazur, M., Śleszyński, P., \& Szejgiec-Kolenda, B. (2020). Wpływ zmian demograficznych w Polsce na rozwój lokalny, Prace Geograficzne, 274. Warszawa: IGiPZ PAN. https://doi.org/10.7163/9788361590873

Wiśniewski, R., Szejgiec-Kolenda, B., \& Śleszyński, P. (2016). Population changes and population ageing in Poland between 1960 and 2011. Geographia Polonica, 89(2), 259-265. https://doi.org/10.7163/GPol.0056

Wites, T. (2007). Wyludnianie Syberii i rosyjskiego Dalekiego Wschodu. Warszawa: Wyd. Uniwersytetu Warszawskiego.

Zborowski, A. (2005). Przemiany struktury społeczno-przestrzennej regionu miejskiego w okresie realnego socjalizmu i transformacji ustrojowej (na przykładzie Krakowa). Kraków: Instytut Geografii i Gospodarki Przestrzennej UJ.

Zborowski, A., \& Gałka, J. (2008). Migracje stałe i czasowe z Polski po akcesji do Unii Europejskiej. W: D. Ilnicki, K. Janc, (red.) Przeksztatcenia Regionalnych Struktur Funkcjonalno-Przestrzennych (s. 29-37), Rozprawy Naukowe Instytutu Geografii i Rozwoju Regionalnego Uniwersytetu Wrocławskiego, 3, Wrocław: Instytut Geografii i Rozwoju Regionalnego Uniwersytetu Wrocławskiego.

Zdrojewski, Z.E. (2000). Wpływ migracji definitywnych na przyrost rzeczywisty i zmiany struktur ludności w Polsce w latach 1975-1996. Koszalin: Politechnika Koszalińska. 


\section{Summary}

This article summarises a review of geographical studies on migration published in Poland after 1989, as also included in the Report of the Polish Academy of Sciences' Migration Research Committee (Komitet Badań nad Migracjami) (Horolets et al., 2018). The work identifies around 750 bibliographical items from the years 1990-2017, which it proves possible to assign to the categories of: the theory and methodology of geographical research into migration (including modelling and forecasting), internal migrations, external migrations (emigration and immigration), studies concerning foreign territories, research into migration historically (pre-WW2), and work concerning migration's influence and impact on regional and local development. As is clear, no attention has been paid to issues of daily mobility (commutes to work or school), tourism (be that recreational, or related to business or pilgrimage), or to longer-term matters relating to ethnicity or multiculturalism. The review has also been supplemented to include work from the latest (2016-2020) period.

The studies that have been run prove to be of an empirical nature first and foremost, associated with the statistical and cartographic identification and description of observed phenomena and processes. This identification is most often based on secondary data from Poland's Główny Urzad Statistyczny or GUS - known in English as the Central Statistical Office and more recently Statistics Poland - which deals with the ongoing processing of new registrations in the country, as well as deregistration. It seems that these data have been accepted more or less uncritically by most geographers, at least until recently. As the strands of research represented least abundantly are modelling, as well contributions to theory, this needs to be seen as marked regression in comparison with the situation in the 1970s - marking the zenith of Polish geographical work on migrations (or indeed more broadly on the processes of population and settlement).

Set against the background of other disciplines, this denotes further a very large number of studies identified as geographical but not equating automatically to progress of a conceptual or theoretical nature. In contrast, a plus-point where the comparison is with typically statistical or demographic research, or partly even that of a sociological and economic nature, is a very good level of" feeling for/sensitivity to the space" (and hence familiarity with local factors), that allows us to avoid over-averaging or generalisation in the direction of aggregate territories known to be too heterogeneous (not least the voivodeships into which Poland has long been divided at provincial - latterly provincial/ regional - level). Avoided in this way is resort to over-generalised cognitive impacts in essence straying beyond the boundaries of geography into other disciplines (economics in particular).

The main and most-original achievements of post-1989 geographical research can be seen to include:

- multi-regional modelling of the dynamics to population change that takes account of the complexity of migration processes (Korcelli and Kupiszewski) - this being a typically" demographic" achievement, but also a good example of work done from the points of view of several different disciplines, albeit with unified methodology;

- retrospective research into population mobility and dynamics as set against conditioning of a nationality-related or ethnic nature, and as provoked inter alia by the First and Second World Wars (Eberhardt); 
- a particularly exhaustive and comprehensive reconnaissance and treatment of the migration-related specifics of the Opole-Silesia region (Dybowska, Heffner, Jończy, Kubiciel-Lodzińska, Rauziński, Rokita-Poskart, Solga, Szczygielski, et al.), whose virtues also include a successful breaking-down of divisions between geography and economics, with the two research disciplines brought closer together to the benefit of both;

- comprehensive and synthetic recognition of population-related and migratory phenomena and processes pertaining to Poland through the whole of the $20^{\text {th }}$ century (Eberhardt and Gawryszewski);

- work on the role played by migration (and mobility more broadly) in the development of suburban zones and metropolitan areas (Gałka, Kurek, Mantey, Potrykowska, Szymańska, Śleszyński and Zborowski), including in the cases of broader settlement complexes (Kłosowski, Runge and Szajnowska-Wysocka);

- migration research into foreign territories, especially in Latin America (Bonasewicz, Lisowska-Jaegermann, Skoczek, et al.); as well as groundbreaking historical studies of the migrations made by Poles into southern Africa (Kowalski);

- in-depth research into the linkage between migration and local or regional socioeconomic development (Długosz, Jażewicz, Jończy, Heffner, Solga, Śleszyński and Wites);

- a contribution to the classification, typology, delimitation and indication of migration, as well as the deployment of indicators in procedures of this type, in a context that is broader where scientific disciplines are concerned (Długosz, Kupiszewski, Kurek and Śleszyński);

- the empirical indication of population over- or under-estimates in different configurations of space as a reflection of unregistered migrations (Dybowska, Heffner, Jończy, Śleszyński);

- contributions to urbanisation theory (Zborowski), including as regards the relations pertaining between migrations and the settlement system (Korcelli). 